\title{
GEOCHEMICAL AND MINERALOGICAL ANALYSIS OF KASHMIR CAVE (SMAST), BUNER, PAKISTAN, AND ISOLATION AND CHARACTERIZATION OF BACTERIA HAVING ANTIBACTERIAL ACTIVITY
}

\author{
Sahib Zada ${ }^{1}$, Abbas Ali Naseem², Seong-Joo Lee², Muhammad Rafiq ${ }^{1}$, Imran Khan ${ }^{1}$, \\ Aamer Ali Shah ${ }^{1}$, AND Fariha HASAN ${ }^{*}$
}

\begin{abstract}
Bacterial strains having the ability to inhibit the growth of other bacteria were isolated from soil samples collected from Kashmir Smast (smast is Pushto for cave), Khyber Pakhtunkhwa, Pakistan. The study includes mineralogical and geochemical analyses of soil sample collected from the cave, so as to describe the habitat from which the microorganisms have been isolated. Total bacterial count of the soil sample was $5.25 \times 10^{4} \mathrm{CFU} \mathrm{mL} \mathrm{m}^{-1}$. Four bacterial isolates having activity against test organisms Micrococcus luteus, Klebsiella sp., Pseudomonas sp., and Staphylococcus aureus were screened out for further study. Two of the isolates were found to be Gram-positive and the other two Gram-negative. The four isolates showing antibacterial activity were identified as Serratia sp. KC1-MRL, Bacillus licheniformis KC2-MRL, Bacillus sp. KC3-MRL, and Stenotrophomonas sp. KC4-MRL on the basis of 16S rRNA sequence analysis. Although all isolates showed antibacterial activity, only Bacillus licheniformis KC2-MRL was selected for further study due to its large zone of inhibition. Antibacterial activity of $B$. licheniformis $\mathrm{KC2}-\mathrm{MRL}$ was optimum when grown in nutrient broth adjusted to $\mathrm{pH} 5$ and after 24 hours of incubation at $35{ }^{\circ} \mathrm{C}$. The extracted antibacterial compound was stable at $\mathrm{pH} 5-7$ and $40{ }^{\circ} \mathrm{C}$ when incubated for 1 hour. The strain was found resistant against cefotaxime (ctx). Atomic-absorption analysis of the soil sample collected from the cave showed high concentrations of calcium $\left(332.938 \mathrm{mg} \mathrm{kg}^{-1}\right)$ and magnesium $\left(1.2576 \mathrm{mg} \mathrm{kg}^{-1}\right)$ compared to the control soil collected outside the cave. FTIR spectrum of the concentrated protein showed similarity to bacitracin. The antibacterial compound showed activity against both Gram-negative and positive test strains. Mineralogy of Kashmir Smast is diverse and noteworthy. Different geochemical classes identified by $\mathrm{X}$-ray diffraction were nitrates, oxides, phosphates, silicates, and sulfates. Weathered cave limestone contributes notably to the formation of these minerals or compounds. FTIR spectroscopic analysis helped to identify minerals such as quartz, clinochlore, vermiculite, illite, calcite, and biotite.
\end{abstract}

\section{INTRODUCTION}

Caves are characterized as having very low nutrient availability, constant low temperatures, and high humidity. Caves can be either terrestrial or aquatic and are usually oligotrophic in nature (i.e., nutrient limited). Some may be rich in specific natural minerals or be exposed to different nutrient-containing sources, therefore, different caves will have different types of microorganisms inhabiting various ecological niches. Fauna, environmental factors, temperature, and organic matter dictate the caves' biotic activities, such as nutrient cycling and geomicrobiological activities, including formation or alteration of cave structures (Adetutu and Ball, 2014).

Cave organisms have evolved some extraordinary abilities to survive and live in this inhospitable environment (Engel et al., 2005; Simmons et al., 2008; Northup and Lavoie, 2004). Cave microbial flora is rich in different types of microorganisms having some diverse and unique characteristics (Groth et al., 1999). The most abundant organisms observed in caves are filamentous and belong to the Actinobacteria group, followed by coccoid and bacilli forms (Cuezva et al., 2009). Some pathogenic microorganisms have been reported from Altamira Cave (Jurado et al., 2006). Luong et al. (2010) for the first time reported the recovery of Aurantimonas altamirensis from human medical samples, rather than from a cave. The disease-causing bacteria E. coli and S. aureus have also been isolated from caves (Lavoie and Northup, 2005), as well as species of Pseudomonas, Sphingomonas, and Alcaligenes sp. (Ikner et al., 2007), and Inquilinus sp. (Laiz et al., 1999).

\footnotetext{
* Corresponding author: farihahasan@yahoo.com

${ }^{1}$ Department of Microbiology, Quaid-i-Azam University, Islamabad, Pakistan.

${ }^{2}$ Department of Geology, Kyungpook National University, Daegu 702 - 701, Korea
} 
Caves can be a source of novel microorganisms and biomolecules, such as enzymes and antibiotics, that may be suitable for biotechnological purposes (Tomova et al., 2013). The influence of particular nutrients in antibiotic biosynthesis is caused by the chemical structures of antibiotic substances (Pereda et al., 1998). Rigali et al. (2008) provide evidence that certain substrates and oligotrophic conditions will lead to increased induction of secondary metabolites. Nitrogen from various sources may incorporate in antibiotic molecules as precursors, or their amino groups can transfer to specific intermediate products (Doull and Vining, 1990; Cheng et al., 1993). Nutrient deficiency is responsible for the onset of antibiotic biosynthesis (Demain et al., 1983; Doull and Vining, 1990; Sanchez and Demain, 2002). When carbon or nitrogen is a limiting factor, growth is rapidly reduced and antibiotic biosynthesis occurs in the stationary phase. In other cases, antibiotic production is associated with the growth phase. Due to the oligotrophic environment in cave ecosystems, microorganisms present in the cave compete for nutrients and produce antibiotics against other microbes. Wide-spectrum standard antibiotics, metabolic by-products (organic acids), lytic agents (lysozyme), and other biologically active compounds like exotoxins and bacteriocins are also produced by microbes (Riley and Wertz, 2002; Yeaman and Yount, 2003). The continuous job of scientists is to discover new antibiotics and new source microorganisms. Cave microorganisms can be used for the production of potential new antibiotics.

Antibiotic producing microbes mostly belong to the genera Penicillium, Streptomyces, Cephalosporium, Micromonospora, Bacillus (Park et al., 1998), and Pseudomonas, followed by the enterobacteria, lactobacilli, and streptococci (Bérdy, 2005). More than eight thousand antibiotics are known to exist and hundreds are discovered yearly (Brock and Madigan, 1991), but only a few prove to be commercially useful. About $17 \%$ of these antibiotics are produced by molds and $74 \%$ by actinomycetes (Zhang et al., 2008). Bacillus sp. mostly form peptides and phenazines, which are heterocyclic and derivatives of fatty acids, but the production of macrolactones is very rare (Bérdy, 2005). Gramicidins, polymixins, bacitracins, and some other antibiotics are formed non-ribosomally (Nissen-Meyer and Nes, 1997; Hancock and Chapple, 1999).

The number and species of microorganisms in soil vary in response to environmental conditions such as nutrient availability, soil texture, and type of vegetation cover (Atlas and Bartha, 1998). The soil composition and texture play important role in harboring microbes with unique characteristics. Thus it is important to know about the composition, type, structure, and texture of the soil from which the microorganisms are isolated for research or the production of metabolites such as antibiotics. A great number of antibiotics have been isolated from various microorganisms. Studies are still being conducted to isolate and identify novel antibiotics effective against pathogenic fungi and bacteria.

Microbial species adapt to caves by interacting with minerals there (Barton and Jurado, 2007). The geochemistry and metal content of the cave environment can influence the synthesis of antibiotics by cave bacteria, as metal ions are known to affect the synthesis of microbial metabolites in vitro. Tanaka et al. (2010) made a connection between the rare earth elements scandium and lanthanum and increased activation of the expression of nine genes belonging to nine secondary metabolite-biosynthetic gene clusters of Streptomyces coelicolor A3(2). Investigations on the effect of several metal ions indicated that $\mathrm{Cu}^{2+}, \mathrm{Mn}^{2+}$, and $\mathrm{Fe}^{2+}$ stimulated AK-111-81 biosynthesis by Streptomyces hygroscopicus, depending on their concentration (Gesheva et al., 2005). Divalent ions stimulated the production of polyenes (Georgieva-Borisova, 1974; Liu et al., 1975; Solivery et al., 1988; Park et al., 1998), and $\mathrm{Fe}^{2+}$ and $\mathrm{Mn}^{2+}$ have been found to favor niphimycin production. Soil texture and structure also strongly influence the activity of soil biota. For example, medium textured loam and clay soils enhance activity of microbes and earthworms, whereas fine textured sandy soils, with lower water retention potentials, are not very favorable. Alterations in $\mathrm{pH}$ of the soil can affect metabolism of species, enzyme activity, and availability of nutrients, and thus, are often lethal (Singh and Mishra, 2013).

The aim of the present study was to isolate microbes from the cave having antibacterial activity, identify them and their product, and investigate the geochemistry of the cave to understand the environmental conditions under which these microorganisms are living and producing compounds inhibitory for other microbes.

\section{Materials And Methods}

\section{Sampling Site and Collection of Soll Samples}

Two soil samples were collected from Kashmir Smast (smast in local language means cave), Nanser, Buner, Khyber Pakhtunkhwa (GPS coordinates $34^{\circ} 25^{\prime} 42.12^{\prime \prime} \mathrm{N}$ $72^{\circ} 13^{\prime} 10.82^{\prime \prime} \mathrm{E}$ ) (Fig. 1). The cave is $188 \mathrm{~m}$ long, with average height and width about $28 \mathrm{~m}$ and $25 \mathrm{~m}$, respectively. The Kashmir Smast is one of a series of natural caves in limestone, probably of marine origin, located in the Babozai Mountains between Mardan and Buner in northern Pakistan. According to study of a rare series of bronze coins and artifacts found in the region, the caves and their adjacent valley probably composed a sovereign kingdom in Gandhara, which maintained at least partial independence for almost 500 years, from the fourth to the ninth centuries $\mathrm{AD}$ (Ziad, 2006). It is a limestone cave with internal temperature around $10{ }^{\circ} \mathrm{C}$. The interior of the cave was muddy due to dripping of water from the surface, the only source of water. Soil samples were collected from the cave wall (sample smast-7) and floor (sample smast-5) in sterile Falcon 


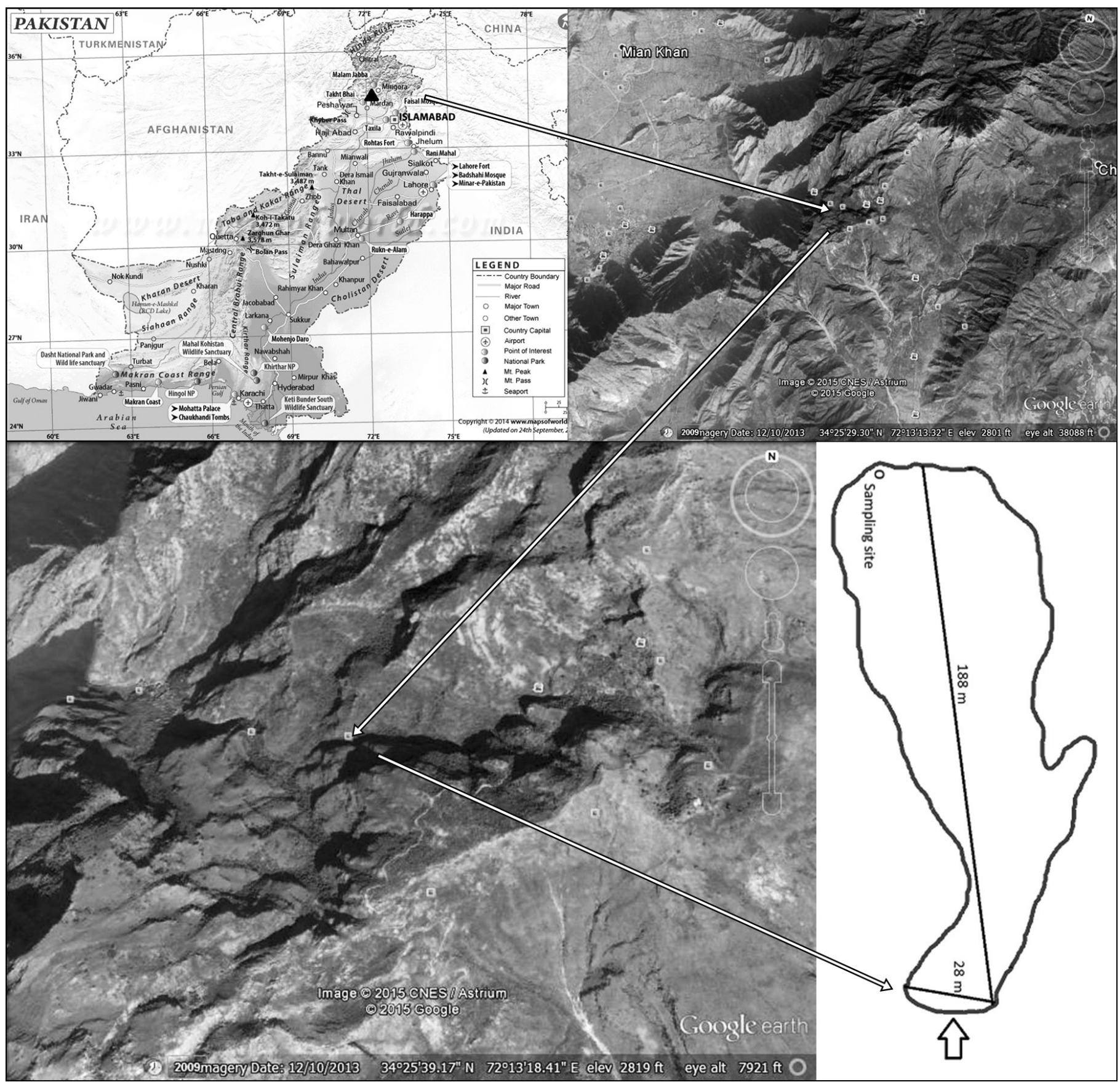

Figure 1. Location and plan map of Kashmir Smast (Cave), Nanseer Buner, Khyber Pakhtunkhwa, Pakistan. White arrows show location of the cave; large arrow shows entrance to the cave. (Pakistan full map from http://www.mapsofworld.com/ pakistan/; aerial images Google Earth.)

tubes under aseptic conditions. The samples were collected from the dark end of the cave about $188 \mathrm{~m}$ from the entrance. This cave is located far away from human travel routes, so human intervention is negligible. The samples were then brought to the laboratory in an icebox and stored at $4{ }^{\circ} \mathrm{C}$ for further processing. These soil samples were screened for the antibiotic-producing isolates within 24 hours.

\section{Mineralogical Analysis}

For the quantitative analysis of elements $(\mathrm{Ni}, \mathrm{Cr}, \mathrm{Co}$, $\mathrm{Cu}, \mathrm{Zn}$ and $\mathrm{Pb}$ ) in the soil sample, Atomic Absorption (AA240FS Fast Sequential Atomic Absorption Spectrophotometer) spectrophotometry was performed. To prepare the sample for this analysis, soil digestion was performed.

One gram each of soil from the cave floor and control soil from outside the cave were ground separately and 
were then mixed in $15 \mathrm{~mL}$ aqua regia, heated at $150{ }^{\circ} \mathrm{C}$, and left overnight. Then $5 \mathrm{~mL}$ of $\mathrm{HClO}_{4}$ was added and again heated at $150{ }^{\circ} \mathrm{C}$. The solution almost became dry until brown fumes were produced. Whatman filter paper (No. 42) was used for filtration, and the volume was made up to $50 \mathrm{~mL}$ using double-distilled water (Jensen et al., 1983).

$\mathrm{X}$-ray powder diffraction is a rapid analytical technique used for phase identification and characterization of unknown crystalline materials such as minerals and inorganic compounds and identification of fine-grained minerals such as clays and mixed-layer clays that are difficult to determine optically (Dutrow and Clark, n.d.). XRD patterns were obtained from the samples using X'Pert-APD (Philips, The Netherlands) with an X-ray generator (1.2 $\mathrm{kW}$ ) and anode (LFF $\mathrm{Cu}$ ). The $\mathrm{Cu} \mathrm{K} \alpha$ radiation had a wavelength of $1.54 \AA$. The X-ray generator voltage and current were $40 \mathrm{kV}$ and $30 \mathrm{~mA}$, respectively. The step-scan data were continuously collected over the range of 5 to $80^{\circ} 2 \theta$.

Mineral proportions were calculated using SIROQUANT, a commercially available MS-Windows program for standardless mineral quantification. Weight-percent mineral phase contents were estimated. Using calculated hkl mineral library files, refinement stages were optimized for the smallest possible $\chi^{2}$ goodness-of-fit parameter for the associated Rietveld peak pattern match (Taylor, 1991; Taylor and Clapp, 1992).

Thermogravimetric analysis records change in mass from dehydration, decomposition, or oxidation of a sample as a function of heating time and temperature (Voitovich et al, 1994). TGA was performed on a high-resolution thermogravimetric analyzer (Staram TGA Instruments, series Q500) in a flowing nitrogen atmosphere $\left(60 \mathrm{~cm}^{3} \mathrm{~min}^{-1}\right)$. Approximately $35 \mathrm{mg}$ of sample underwent thermal analysis, with a heating rate of $5{ }^{\circ} \mathrm{C} \mathrm{min}^{-1}$ within the range of 25 to $1000{ }^{\circ} \mathrm{C}$. With the isothermal, isobaric heating program of the instrument the furnace temperature was regulated precisely to provide a uniform rate of decomposition in the main decomposition stage.

The field-emission cathode in the electron gun of a scanning electron microscope provides narrower probing beams at low, as well as high, electron energy that results in improved spatial resolution and minimizes sample charging and damage (Stranks et al., 1970). FE-SEM with EDS analysis of the samples was performed for the determination of thickness, structure uniformity, and elemental composition, using S-4800 and EDX-350 (Horiba) FE-SEM (Hitachi, Tokyo, Japan). Samples were spread on a glass plate that was fixed onto a brass holder and coated with osmium tetraoxide $\left(\mathrm{OsO}_{4}\right)$ using a VD HPC-ISW osmium coater (Tokyo, Japan) prior to FE-SEM analysis

About $2 \mathrm{mg}$ of the soil sample was mixed with $40 \mathrm{mg}$ of $\mathrm{KBr}$ in ratio 1:20 using mortar and pestle. $\mathrm{KBr}$ powder had been dried at $120{ }^{\circ} \mathrm{C}$ in an oven to avoid the broad spectral peak. A 1 by $13 \mathrm{~mm}$ pellet was prepared. The pellet was placed in a holder and introduced in the infrared beam for analysis through Fourier Transform Infrared Spectrometer (Jasco FT/ IR - 620).

\section{Microbiological Studies}

For isolation of bacteria from the cave soil, $1 \mathrm{~g}$ of each soil sample was serially diluted in normal saline and then was spread on nutrient-agar plates aseptically, and plates were incubated aerobically for $24 \mathrm{hrs}$ at $35{ }^{\circ} \mathrm{C}$. Viable cell count was calculated as CFU mL $\mathrm{m}^{-1}$.

The isolate Bacillus licheniformis KC2-MRL was incubated at 25,35 and $45{ }^{\circ} \mathrm{C}$. A growth curve was constructed by taking values of cell concentration on y-axis versus time along x-axis. Using a standard formula, growth rate and generation time was calculated from the graph.

Nutrient agar medium was used for isolation of antibiotic-producing bacteria. Lawns of susceptible test organisms Micrococcus luteus (ATCC 10240), Klebsiella sp., Pseudomonas sp., and Staphylococcus aureus (ATCC 6538) were made on nutrient agar plates (Gauthier, 1976) that were then sprinkled with 20 to 25 particles of soil. All the plates were gently shaken so that the soil particles spread uniformly. Plates were then incubated at $35^{\circ} \mathrm{C}$ for 24 hours, lid side up so that the soil particles would not fall off the agar. After 24 hours of incubation, plates were checked for antibacterial activity shown by the formation of clear zone of inhibition around the KC2-MRL bacteria colony. Zone-producing isolates were purified and stored at $4{ }^{\circ} \mathrm{C}$. Colony morphology, Gram-staining, and biochemical tests (citrate utilization, oxidase and catalase production, nitrate and sulfate reduction, $\mathrm{H}_{2} \mathrm{~S}$ production, and carbohydrate fermentation) were performed according to Bergey's Manual of Determinative Bacteriology (Holt, 2012).

The DNA extraction from bacteria was done by spinning $1 \mathrm{~mL}$ of culture at $10,000 \mathrm{rpm}$ for about $3 \mathrm{~min}$, after which the cells were pelleted out and rinsed twice in $400 \mu \mathrm{L}$ TE buffer after removing the supernatant. Then the cells were centrifuged at $10,000 \mathrm{rpm}$ for $3 \mathrm{~min}$, and the pellets were resuspended in $200 \mu \mathrm{L}$ TE buffer. Then $100 \mu \mathrm{L}$ Tris-saturated phenols of $\mathrm{pH} 8.0$ were added to these tubes, followed by a vortex-mixing step of $60 \mathrm{sec}$, to lyse the cells. To separate the aqueous and organic phases, the samples were centrifuged at $13,000 \mathrm{rpm}$ at $4{ }^{\circ} \mathrm{C}$ for 5 minutes. Then $160 \mu \mathrm{L}$ of upper aqueous phase was taken in a $1.5 \mathrm{~mL}$ Eppendorf. About $40 \mu \mathrm{L}$ of TE buffer was added to make $200 \mu \mathrm{L}$, which was then mixed with $100 \mu \mathrm{L}$ of $24: 1$ chloroform:isoamyl alcohol and centrifuged for $5 \mathrm{~min}$ at $13,000 \mathrm{rpm}$ at $4{ }^{\circ} \mathrm{C}$. Chloroform:isoamyl alcohol (24:1) extraction was used for the purification of lysate, until there was no longer a white interface, and the same method was repeated twice or thrice (Aitken, 2012). Purified DNA was present in the aqueous phase and was stored at $-20{ }^{\circ} \mathrm{C}$ for further use. The purified DNA was analyzed through agarose gel $1.5 \mathrm{~g}$ in $1 \mathrm{X}$ TBE and staining with ethidium bromide.

Phylogenetic analysis was performed with a ClustalW program implemented in MEGA4.0 (Thompson et al., 1994). The similar sequences were downloaded from NCBI. 
All sequences were aligned, and the phylogenetic tree was constructed using the neighbor-joining method. Bootstrap analysis with 1000 replicates was performed for the significance of the generated tree.

An inoculum of $B$. licheniformis KC2-MRL, selected after screening on the basis of its larger zone of inhibition against test strains, was prepared in nutrient broth. First about $50 \mathrm{~mL}$ of nutrient broth was prepared in $250 \mathrm{~mL}$ flask, autoclaved, and incubated at $35^{\circ} \mathrm{C}$ overnight to check the sterility. The nutrient broth was taken in $100 \mathrm{~mL}$ flasks and its $\mathrm{pH}$ was adjusted to 5 ( $\mathrm{pH}$ of sampling site was 5). Approximately $10 \%$ inoculum was added to each flask and incubated at $35{ }^{\circ} \mathrm{C}$ in orbital shaker at $150 \mathrm{rpm}$. After every $24 \mathrm{hrs}$, samples were collected and centrifuged at 10,000 $\mathrm{rpm}$ for 16 minutes, for a total of $96 \mathrm{hrs}$ to obtain cell free supernatant that was checked for antibacterial activity by agar-well diffusion assay (Haque et al., 1995). About 80 $\mu \mathrm{L}$ of cell-free supernatant was added in the wells and the plates were incubated at $35{ }^{\circ} \mathrm{C}$ for 24 hours. After $24 \mathrm{hrs}$, the zones of inhibition were observed and the diameter of the zone of inhibition was measured.

Different media were used for the production of antibacterial compounds by $B$. licheniformis KC2-MRL, including Trypticase soya broth, nutrient broth and Luria Bertani broth. Inoculum $(10 \%)$ was added and incubated at $37{ }^{\circ} \mathrm{C}$ and $150 \mathrm{rpm}$. The cell growth was measured by optical density at $600 \mathrm{~nm}$, and antimicrobial activity was checked by agar-well diffusion assay.

To check the effect of time of incubation on the antimicrobial activity, the strain was incubated at $37{ }^{\circ} \mathrm{C}$ in orbital shaker at $150 \mathrm{rpm}$ and samples were drawn after every 24 hours from 0 to 96 hours. The antimicrobial activity of all the collected cell-free supernatants was checked against $S$. aureus, M. luteus, Klebsiella sp., and E. coli.

The effect of temperature $\left(15,25,35\right.$, and $\left.45^{\circ} \mathrm{C}\right)$ on optimum antibacterial activity was studied by inoculating $B$. licheniformis $\mathrm{KC2}-\mathrm{MRL}$ in nutrient broth and incubating at $15,25,35$ and $45{ }^{\circ} \mathrm{C}$ at $150 \mathrm{rpm}$. Samples were drawn every 24 hours from 0 to $96 \mathrm{hrs}$. Centrifuged cell-free supernatants were used for further analysis using $S$. aureus, $M$. luteus, Klebsiella sp., and Pseudomonas sp. as test strains.

The effect of $\mathrm{pH}(5,6,7$, and 8$)$ on the production of antibiotics was studied by inoculating $B$. licheniformis $\mathrm{KC} 2-\mathrm{MRL}$ in the growth medium adjusted to those values. Samples were drawn every 24 hours from 0 to 96 hours, and centrifuged and cell free supernatants were used for further analysis.

The standard Kirby-Bauer disk-diffusion assay (Koneman, 2006) was performed to check the sensitivity of the selected strains against various broad-spectrum antibiotics to check for the intrinsic ability of the microorganisms to resist antibiotics.

Cell-free supernatant of $B$. licheniformis KC2-MRL culture grown under optimized conditions was used for the precipitation of antibacterial compounds using increasing concentrations of 10 to $80 \%$ of ammonium sulfate. The pellet was kept at $-20{ }^{\circ} \mathrm{C}$ in $10 \mathrm{~mL}$ of $0.1 \mathrm{M}$ phosphate buffer, pH 7. FTIR was performed to identify unknown compounds. Spectrum of the antibacterial compound produced by Bacillus licheniformis KC2-MRL was compared with that of bacitracin as a control. Samples were scanned from $4000-400 \mathrm{~cm}^{-1}$ at resolution of $6.0 \mathrm{~cm}^{-1}$.

\section{RESULTS}

\section{Mineralogical Analysis}

Observed X-ray diffraction patterns of samples smast-5 and smast-7 along with the Inorganic Crystal Structure Database reference data of different minerals are shown in Figures $2 \mathrm{a}$ and $2 \mathrm{~b}$. In Figure $2 \mathrm{a}$, two prominent peaks at $2 \theta 26.624$ and 29.420 were observed. The observed peaks match with the ICSD Reference codes 03-065-0466 Quartz and 01-086-1385 Muscovite-2M1. Along with these peaks, some other weak peaks matched with reference peaks of 01-075-8291 Chlorite-11-4, 01-080-1108 Biotite, 01-0751656 Dolomite, 01-077-0022 Vermiculite-2M, and 01-0758291 Clinochlore-1lb-4. Figure $2 \mathrm{~b}$ indicates three prominent peaks at $2 \theta 26.661,29.442$, and 30.984 . These matched with ICSD Reference codes 01-087-2096 Quartz, 01-072-4582 Calcite, and 01-076-6603 Vermiculite. Silicate minerals found in the cave were illite, muscovite, vermiculite, chlorite, clinochlore, and quartz. The chemical composition of the minerals is given in Table 1 .

Weight-percent mineral phases were used to estimate the SIROQUANT (Fig. 3), considering 100\% crystalline compound to calculate the quantitative analysis. Figure $3 \mathrm{a}$ shows that vermiculite, illite, and chlorite were the most abundant minerals in smast-5. Similarly, Figure $3 \mathrm{~b}$ shows that the vermiculite-2M1, muscovite, and clinochlore-1lb are the most abundant minerals in smast-7.

The Fourier-transform infrared absorption peaks from the cave were observed to determine the major and minor constituent minerals present in the sample smast-7 (Fig. 4). The samples analyzed were mixtures of minerals such as silicon oxide, calcite, quartz, muscovite, clinochlore, nimite, biotite, and vermiculite. Various peaks appeared indicating the presence of a variety of minerals.

Mass loss steps were observed from Figure 5 at 77, 200 and 280,400 and $790{ }^{\circ} \mathrm{C}$, with mass losses of $10.23,21.55$, 5.20 and $7.58 \%$ recorded due to carbonates.

Scanning electron microscope observations (Fig. 6) suggest that cave's clay particles are poorly crystallized clasts with angular, irregular outlines, and swirly texture with face-to-face arrangement of clay grains. Si, Al, and Fe were found enriched within the samples.

\section{SoIL AnALysis}

Atomic-absorption spectroscopy was performed to determine the concentration of elements in the cave soil sample smast-5. Ca was $332.938 \mathrm{mg} \mathrm{kg}^{-1}$ as compared to $121.65 \mathrm{mg} \mathrm{kg}^{-1}$ in control soil from the surface, $\mathrm{Mg}$ was 

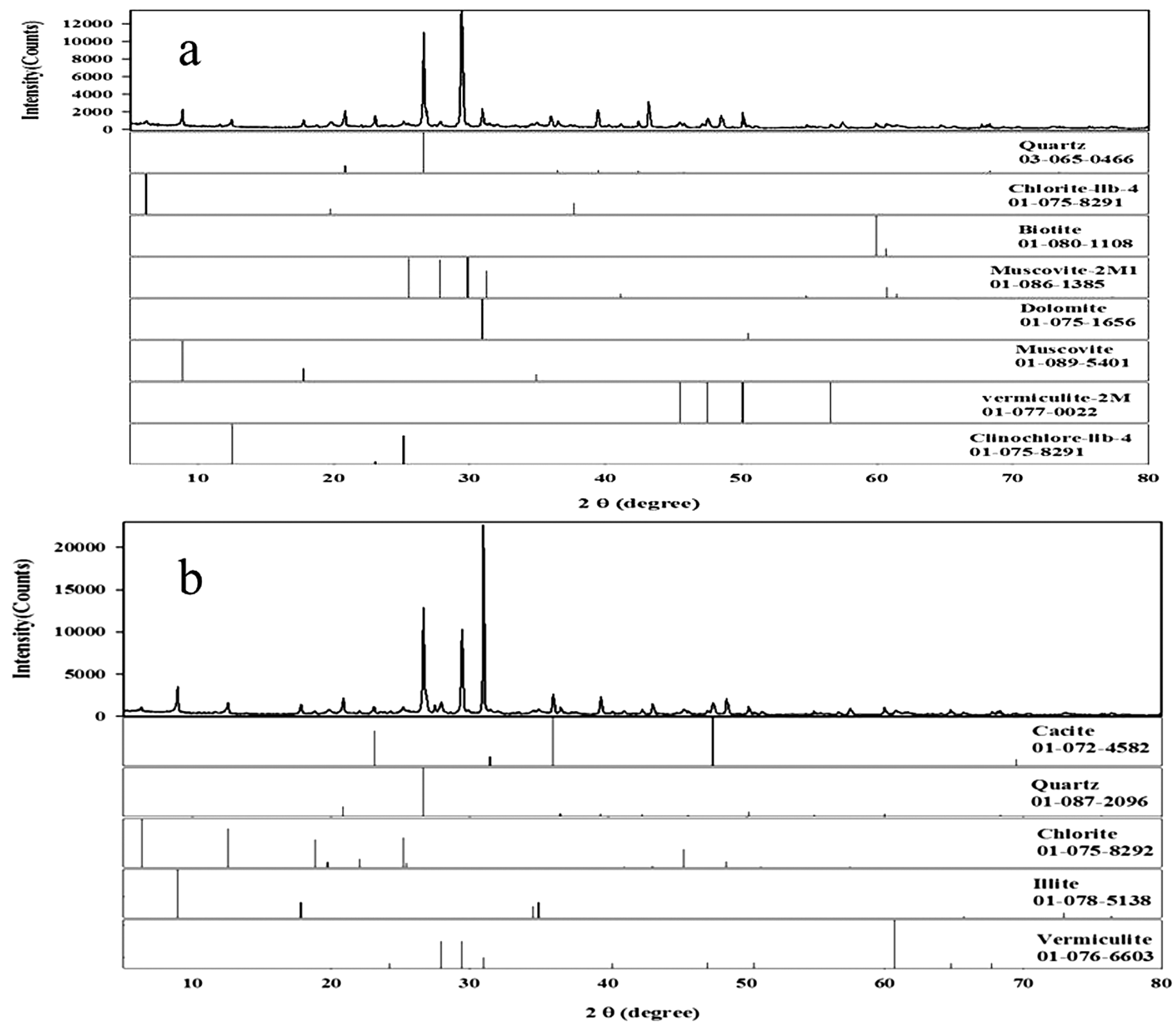

Figure 2. X-ray diffraction patterns of Kashmir Smast soil samples smast-5 from the floor (a) and smast-7 from the wall (b) with spectra from the Inorganic Crystal Structure Database for comparison and identification.

$1.2576 \mathrm{mg} \mathrm{kg}^{-1}$ in cave soil and $1.023 \mathrm{mg} \mathrm{kg}^{-1}$ in control soil, and that of $\mathrm{Ni}, \mathrm{Cr}, \mathrm{Co}, \mathrm{Cu}, \mathrm{Zn}$, and $\mathrm{Pb}$ were much lower than those found in the control soil (Table 2).

\section{Microbiology Results}

Numbers of viable cells per $\mathrm{mL}$ were calculated for the smast-7 floor-soil sample collected from Kashmir Cave. The bacterial count (CFU) was $5.25 \times 10^{4} \mathrm{~mL}^{-1}$.

Initial screening resulted in isolation of four phenotypically distinct bacterial strains showing antimicrobial activity against four test organisms. Figure 7 shows a typical nutrient-agar plate with zones of inhibition. Of the four, the strain B. licheniformis KC2-MRL showed the largest zones of inhibition,
$28 \mathrm{~mm}$ against Micrococcus, $20 \mathrm{~mm}$ against E. coli, $14 \mathrm{~mm}$ against Staphylococcus aureus, and $15 \mathrm{~mm}$ against Klebsiella). Therefore it was selected for further analysis.

The 16S rRNA gene sequences of the antibiotic-producing cave bacteria have been submitted to NCBI GenBank. The isolates $\mathrm{KC1}-\mathrm{MRL}, \mathrm{KC2}-\mathrm{MRL}, \mathrm{KC} 3-\mathrm{MRL}$ and KC4-MRL were identified as Serratia sp. KC1-MRL (Accession No. KC128829.1), Bacillus licheniformis KC2MRL (Accession No. KC128830.1), Bacillus sp. KC3MRL (Accession No. KC128831.1), and Stenotrophomonas sp. KC4-MRL (Accession No. KC128832.1) (Fig. 8).

Maximum antimicrobial activity was found when B. licheniformis $\mathrm{KC2}-\mathrm{MRL}$ was cultured in nutrient broth 
Table 1. List of minerals identified in samples from the wall and floor of Kashmir Smasta.

\begin{tabular}{ll}
\hline Mineral & \multicolumn{1}{c}{ Chemical Formula } \\
\hline Calcite & $\mathrm{CaCO}_{3}$ \\
Quartz & $\mathrm{SiO}_{2}$ \\
Dolomite & $\mathrm{CaMg}_{\left(\mathrm{CO}_{3}\right)_{2}}$ \\
Muscovite-2M1 & $\mathrm{K}_{0.86} \mathrm{Al}_{1.94}\left(\mathrm{Al}_{0.965} \mathrm{Si}_{2.895} \mathrm{O}_{10}\right)\left((\mathrm{OH})_{1.744} \mathrm{~F}_{0.256}\right)$ \\
Muscovite & $\mathrm{KAl}_{2.20}\left(\mathrm{Si}_{3} \mathrm{Al}\right)_{0.975} \mathrm{O}_{10}\left((\mathrm{OH})_{1.72} \mathrm{O}_{0.28}\right)$ \\
Clinochlore-1lb & $\left(\mathrm{Mg}_{4.715} \mathrm{Al}_{0.394} \mathrm{Fe}_{0.109} \mathrm{Cr}_{0.128} \mathrm{Nl}_{0.011}\right)\left(\mathrm{Si}_{3.056} \mathrm{~A}_{1.944}\right) \mathrm{O}_{10}(\mathrm{OH})_{8}$ \\
Biotite & $\mathrm{KFeMg}_{2}\left(\mathrm{AlSi}_{3} \mathrm{O}_{10}\right)(\mathrm{OH})_{2}$ \\
Vermicullite-2M & $\left(\mathrm{Mg}_{2.36} \mathrm{Fe}_{0.48} \mathrm{Al}_{0.16}\right) \mathrm{Mg}_{0.32}\left(\mathrm{Al}_{1.28} \mathrm{Si}_{2.72}\right) \mathrm{O}_{10}(\mathrm{OH})_{2}\left(\mathrm{H}_{2} \mathrm{O}\right)_{4.32} \mathrm{Mg}_{0.32}$ \\
Vermicullite & $\mathrm{Mg}_{3}\left(\left(\mathrm{AlSi}_{3} \mathrm{O}_{10}\right)(\mathrm{OH})\left(\mathrm{H}_{2} \mathrm{O}\right)\right.$ \\
Chlorite-llb-4 & $\left(\mathrm{Mg}_{11.06} \mathrm{Fe}_{0.94}\right)\left(\left(\mathrm{Si}_{5.22} \mathrm{Al}_{2.78}\right) \mathrm{O}_{20}(\mathrm{OH})_{16}\right)$ \\
Illite & $\left(\mathrm{K}_{0.71} \mathrm{Ca}_{0.01} \mathrm{Na}_{0.01}\right)\left(\mathrm{Al}_{1.86} \mathrm{Mg}_{0.15} \mathrm{Fe}_{0.04}\right)\left(\left(\mathrm{Si}_{3.27} \mathrm{Al}_{0.73}\right) \mathrm{O}_{10}(\mathrm{OH})_{2}\right)$ \\
\hline
\end{tabular}

after 24 hours of incubation, with zone of inhibition of 28 $\mathrm{mm}$ against $M$. luteus, $20 \mathrm{~mm}$ against $S$. aureus, $11 \mathrm{~mm}$ against Klebsiella and $8 \mathrm{~mm}$ against $E$. coli. The antibacterial activity decreased with passage of time in all media except the nutrient broth.

Best antimicrobial activity $(21 \mathrm{~mm})$ of $B$. licheniformis KC2-MRL was observed against $M$. luteus, $14 \mathrm{~mm}$ against S. aureus, $12 \mathrm{~mm}$ against Klebsiella, and $8 \mathrm{~mm}$ against E. coli after 48 hours of incubation, while there was a decrease in the sizes of zones after 48 hours showing decrease in antimicrobial activity of $B$. licheniformis KC2MRL (Fig. 9).

Maximum antibacterial activity of $28 \mathrm{~mm}$ and $22 \mathrm{~mm}$ was observed against $S$. aureus and $M$. luteus, respectively, with $17 \mathrm{~mm}$ against $E$. coli and $9 \mathrm{~mm}$ activity against Klebsiella, at $35{ }^{\circ} \mathrm{C}$ after $48 \mathrm{hrs}$ of incubation. The activity in terms of zones of inhibition decreased with further increase in temperature $\left(45^{\circ} \mathrm{C}\right)$ (Fig. 9).

Effect of $\mathrm{pH}(5,6,7$, and 8$)$ on the production of antibiotics was studied. Activity in terms of zones of inhibition was measured against the same test organisms. Best activities were observed at $\mathrm{pH} 5,23 \mathrm{~mm}$ against $S$. aureus, followed by $M$. luteus, E. coli and Klebsiella after $24 \mathrm{hrs}$ of incubation. The second best activity was observed at $\mathrm{pH} 6$, and a gradual decrease in activity was observed with increase in pH (Fig. 9).

To check the stability of antimicrobial compounds at different temperatures, the cell free supernatant was treated at $15,25,35$, and $45{ }^{\circ} \mathrm{C}$ for 1 hour. Antibacterial activity ( 26 mm) was observed until $40{ }^{\circ} \mathrm{C}$, but the activity decreased at a temperature above $40{ }^{\circ} \mathrm{C}$ and was totally lost with further rise in temperature. The antimicrobial compound produced by $B$. licheniformis $\mathrm{KC2}-\mathrm{MRL}$ was stable at $\mathrm{pH}$ $5-8$, although highest activity was observed at $\mathrm{pH} 5$ and 6 , whereas activity decreased at $\mathrm{pH} 7$ and 8 .

Vancomycin, nalidixic acid, cefotoxime, ampicillin, amoxicillin, imipenem, methicillin, cefotetan, and levofloxacin were tested to check the susceptibility of Bacillus licheniformis KC2-MRL. The organism was more susceptible to levofloxacin, which produced a $40 \mathrm{~mm}$ zone of inhibition (Fig. 10).

We used a solution of bacitracin as a standard. FTIR spectrum of $B$. licheniformis KC2-MRL's precipitated protein was compared with the standard. The FTIR spectrum

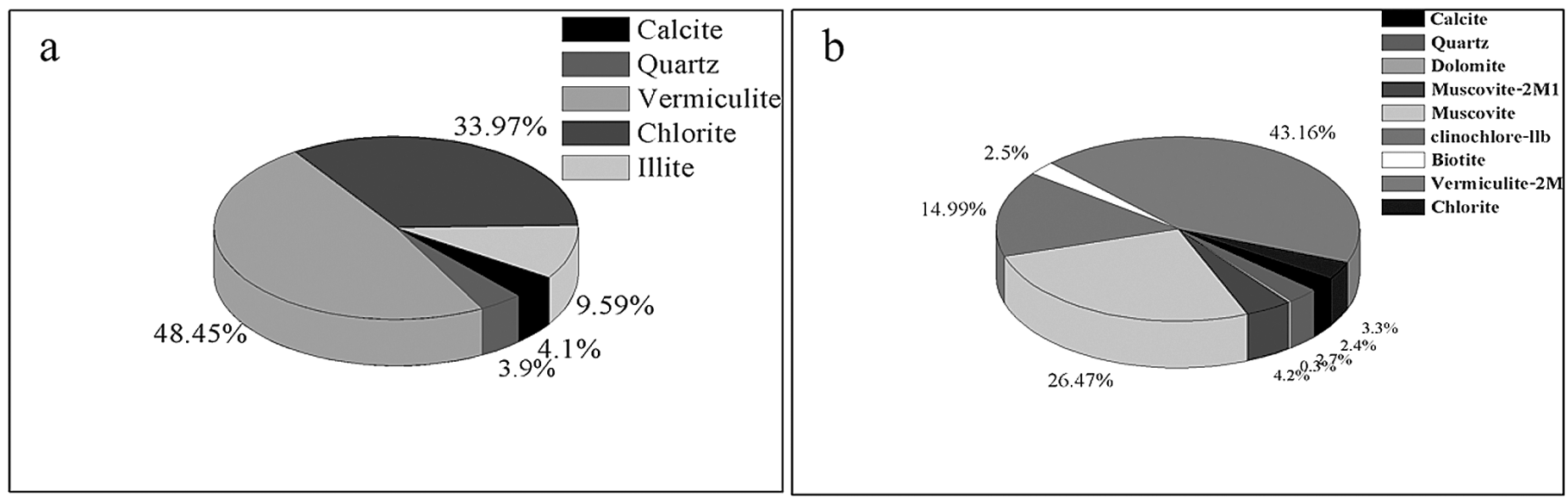

Figure 3. Distribution of minerals identified in soil sample smast-7 from wall (a) and smast-5 from floor (b). 


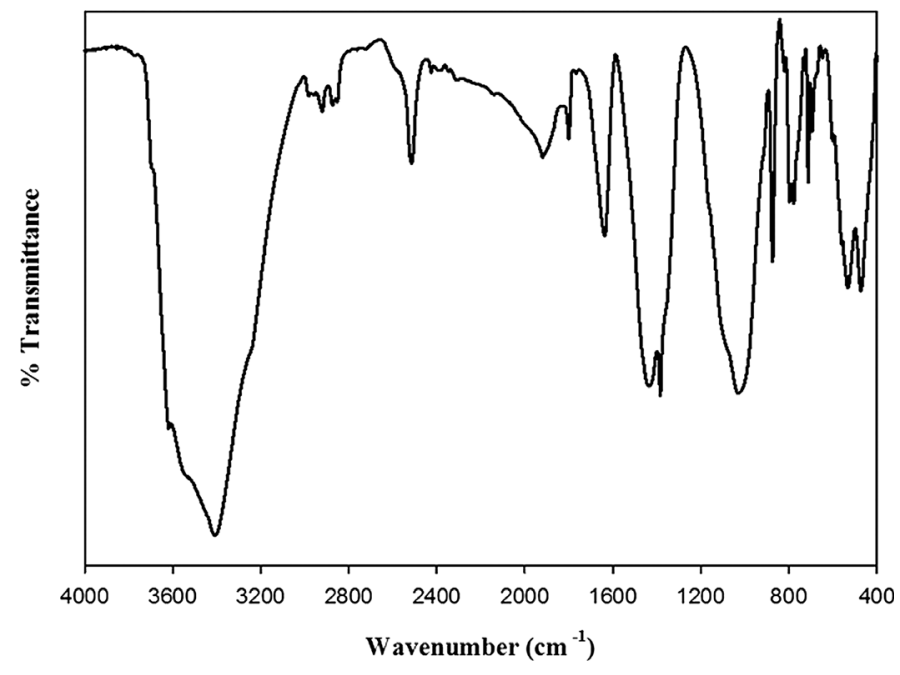

Figure 4. Fourier-transform infrared absorption spectrum of soil sample smast-7 from the cave wall.

of bacitracin showed the absorption bands at 3295.63, $3016.9,2133.64$, and $1635 \mathrm{~cm}^{-1}$ that correspond to $\mathrm{NH}$, $\mathrm{CH}, \mathrm{C}-\mathrm{C}$, and $\mathrm{C}=\mathrm{C}$ groups. Similarly, in the case of $B$. licheniformis $\mathrm{KC} 2-\mathrm{MRL}$ protein the absorption bands appeared at 3271.98, 3016.90, 2120.12, 1635.20 and $1076.22 \mathrm{~cm}^{-1}$ which were attributing to $\mathrm{NH}, \mathrm{CH}, \mathrm{C}=\mathrm{C}$ and $\mathrm{C}-\mathrm{N}$ (Fig. 11).

\section{Discussion}

Solution caves are formed in carbonate and sulfate rocks such as limestone, dolomite, marble, and gypsum by the action of slowly moving groundwater that dissolves the rock to form tunnels, irregular passages, and even large caverns along joints and bedding planes (Davies and Morgan, 2000). Caves usually have very low nutrient availability, but they still contain diverse, and often unique, microbial communities (Barton, 2006). Caves on other worlds such as Mars may provide protected sites for extraterrestrial life forms (Nelson, 1996). The subsurface of Earth is considered as the best possible site to look for microbial life and the characteristic lithologies that indicates the remnants of life (Boston et al., 2001). Microbial analysis of caves showed Bacillus as the most commonly detected microbial genus (Adetutu et al., 2012). It is important to understand how
2D Graph 1

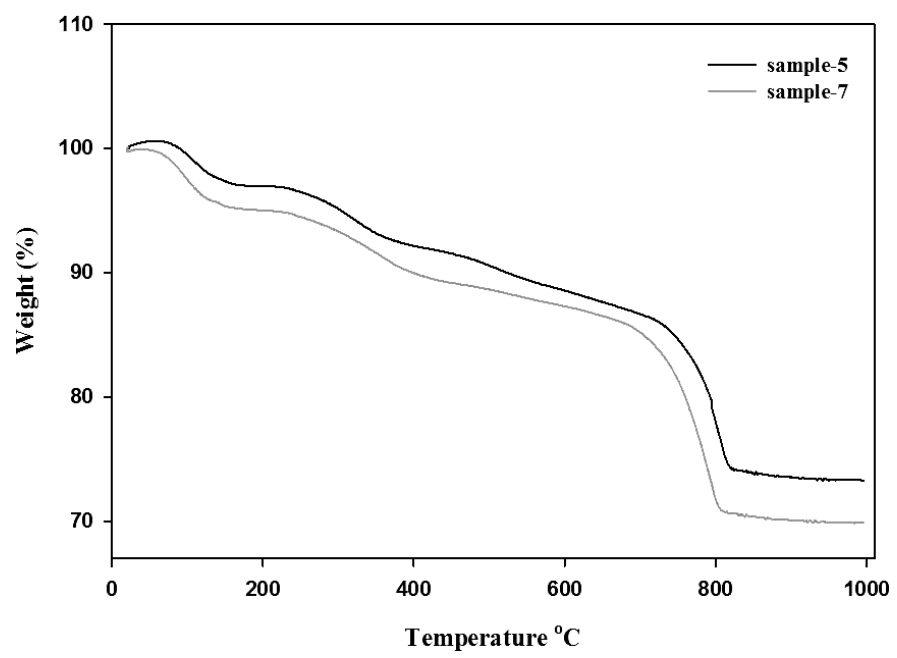

Figure 5. Thermogravimetric analysis plots of Kashmir Smast soil samples 5, cave soil, and 7 , cave wall.

the ecosystems are operating and accommodating microbial diversity. The rock composition and mineralogy can be helpful to understand the geomicrobiology and potential metabolic capabilities of the microorganisms to use ions within the rock as nutrients and for chemolithotrophic energy production. Cave sediments can therefore act as reservoirs of microorganisms (Adetutu et al., 2012). The use of these ions may be supported by the formation of a corrosion residue, through microbial scavenging activities (Barton, 2006). Cave microorganisms also have potential to produce unique antibiotics and cancer treatment drugs (Onaga, 2001). Minerals have profound effect on the production of antibiotics by microorganisms. Basak and Majumdar (1975) reported that kanamycin production by Streptomyces kanamyceticus ATCC 12853 required magnesium sulfate and potassium phosphate $\left(0.4\right.$ and $1.0 \mathrm{~g} \mathrm{~L}^{-1}$, respectively) and $\mathrm{Fe}$ and $\mathrm{Zn}\left(0.25\right.$ and $0.575 \mu \mathrm{g} \mathrm{mL}{ }^{-1}$, respectively), amounts of $\mathrm{Mn}$ and $\mathrm{Ca}$ did not have any effect, and $\mathrm{Cu}, \mathrm{Co}, \mathrm{Ni}$, and $\mathrm{V}$ have inhibitory effect. Divalent ions as $\mathrm{Mn}^{2+}, \mathrm{Cu}^{2+}, \mathrm{Fe}^{2+}$ stimulated AK-111-81 antibiotic biosynthesis by Streptomyces hygroscopicus 111-81 (Gesheva et al., 2005). The divalent metal ions ( $\mathrm{Mg}, \mathrm{Fe}$ and $\mathrm{Mn}$ ) sodium dihydrogen phosphate were found essential for bacitracin production by Bacillus licheniformis,

Table 2. Concentrations of some metals from soil sample collected from the floor of Kashmir Smast and control sample from outside the cave, determined by atomic-absorption spectroscopy.

\begin{tabular}{lcccccccc}
\hline & \multicolumn{7}{c}{ Metals, $\mathrm{mg} \mathrm{kg}^{-1}$} \\
\cline { 2 - 9 } Soil Samples & $\mathrm{Ni}$ & $\mathrm{Cr}$ & $\mathrm{Co}$ & $\mathrm{Cu}$ & $\mathrm{Zn}$ & $\mathrm{Ca}$ & $\mathrm{Mg}$ & $\mathrm{Pb}$ \\
\hline Cave Soil & 0.965 & 0.571 & 0.266 & 1.824 & 12.7311 & 332.938 & 1.2576 & 1.31 \\
Control Soil & 10.4 & 8.74 & 0.810 & 4.7 & 36.41 & 121.65 & 1.023 & 8.14 \\
\hline
\end{tabular}



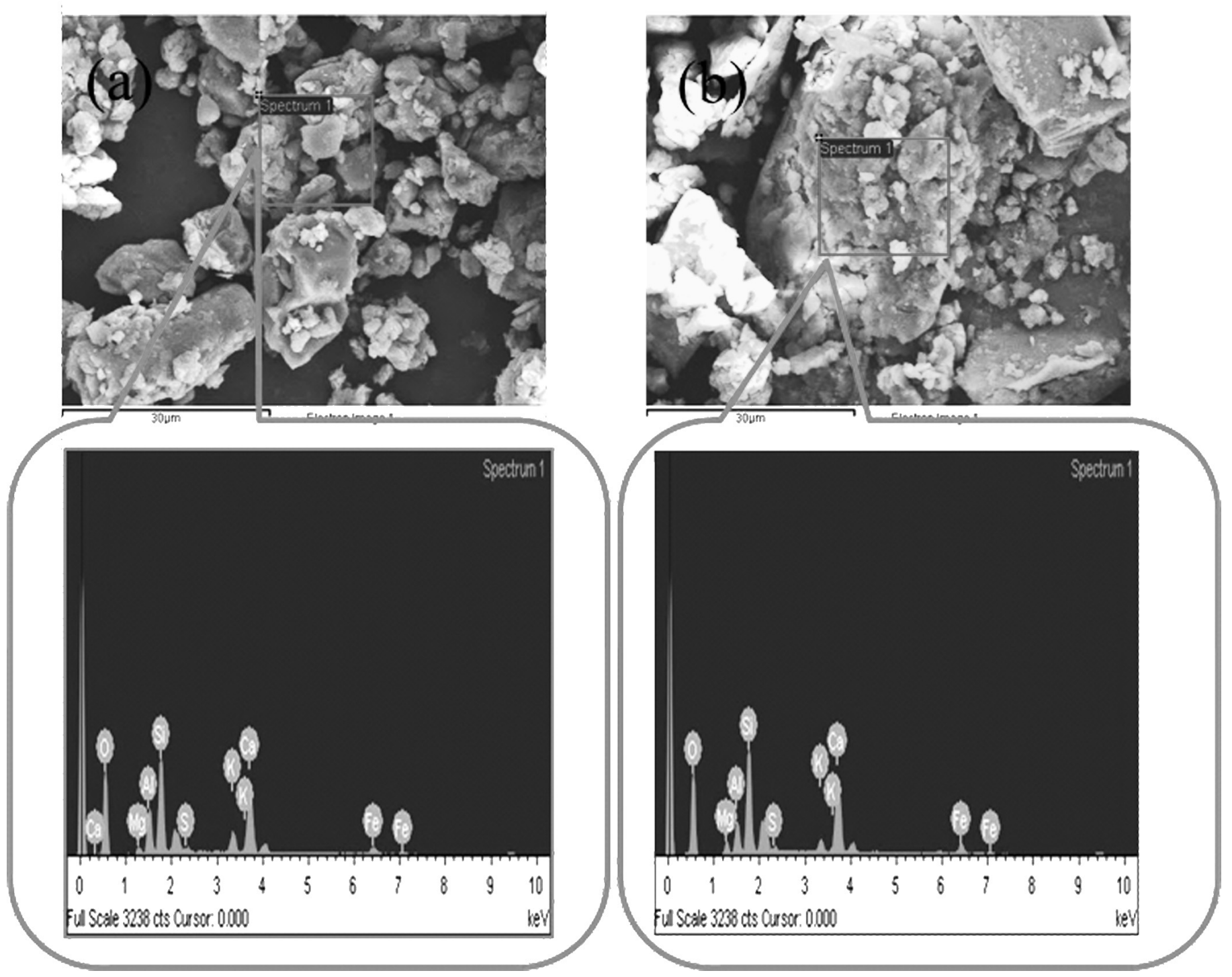

Figure 6. Scanning electron micrograph and energy-dispersive X-ray spectroscopy results for samples smast-7 from cave wall (a) and smast-5 from cave floor (b).

whereas $\mathrm{Na}_{2} \mathrm{SO}_{4}$ and $\mathrm{CaCl}_{2}$ decreased the bacitracin yield (Yousaf, 1997).

The soil sample from which $B$. licheniformis $\mathrm{KC} 2-\mathrm{MRL}$ was isolated was reddish-brown in color. Brown soils are usually low in organic matter. Terra rossa is a soil that is heavy and clay-rich soil, strongly reddish, developed on limestone or dolomite, usually derived from the insoluble residue of the underlying rock. Following dissolution of calcium carbonate by rain, clay contained in limestone sediments, along with other insoluble substances or rock fragments, forms discontinuous residual layers variable in depth. Under oxidizing conditions iron oxides appear that produce the characteristic red color. According to this theory, terra rossa is usually considered a polygenetic relict soil, formed during the Tertiary and subjected to hot and humid periods during the Quaternary (Jordán, 2014).
X-ray diffraction analysis of the cave sample confirmed the presence of clay minerals, carbonates, and silicates (Hill, 1999). Minerals are produced as a result of intense chemical weathering on land under possibly tropical conditions, where abundant rainfall favored ionic transfer and pedogenic development (Millot, 1970).

Carbonates found in Kashmir Smast are predominantly calcite and traces of dolomite (Vogel et al., 1990; Schwabe et al., 1993). In caves, illite is found mostly in fault zones and also occurs as clay floor deposits (Hill, 1999). Illite is commonly present as little-altered, disintegrated particles (Weaver, 1989). Pedogenic clay minerals are derived from moderate chemical weathering and generally develop in poorly drained tropical to subtropical areas of low relief, marked by flooding during humid seasons and subsequent concentration of solutions in the soil during dry seasons. 


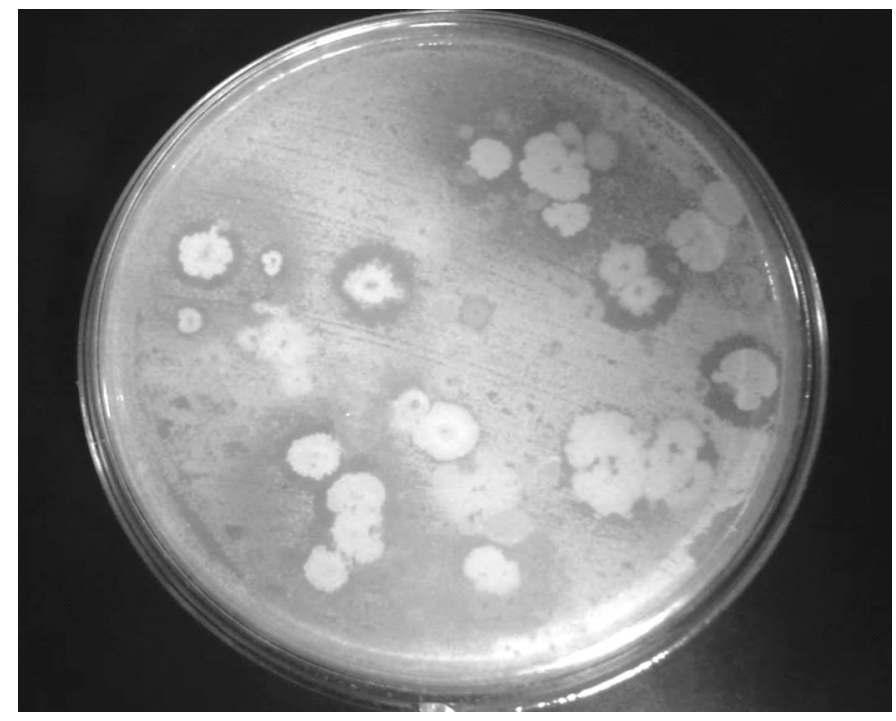

Figure 7. Nutrient-agar plate showing typical zones of inhibition due to antimicrobial activity against a test strain.

$\mathrm{Al}, \mathrm{Fe}$, and $\mathrm{Si}$ are transported by means of water saturation during wet seasons; concentration for mineral growth takes place during in dry seasons (ChamLey, 1989). During pedogenesis, chlorite transforms into kaolinite, and in intensely weathered laterite soils chlorite would be completely eliminated (Vicente et al., 1997). The accumulations of illite, kaolinite, chlorite, dolomite, and muscovite in Kashmir Smast are probably indicative of changes in degree of weathering, and thus reflect the changes in climatic conditions. The degree of weathering related to the presence of $\mathrm{SiO}_{2}$ and $\mathrm{Al}_{2} \mathrm{O}_{3}$ shows a similar pattern to clay minerals (Tardy and Nahon, 1985; Zhao and Yang, 1995). The mineral assemblages investigated in the cave are diverse.

The quantitative mineral analysis technique SIROQUANT determined mineral compositions of rocks, including clay mineral content. Thermal analysis offers an important technique for the determination of thermal stability of minerals and roughly estimating organic content of samples. Importantly, the decomposition curves can be obtained and mechanism of decomposition of the mineral determined. Generally, the theoretical mass loss of water is $10.46 \%$, and structural disorganization upon thermal treatment may occur in response to the loss of hydration water, which could provoke collapse of the crystalline structure (Doak et al., 1965). The two overlapping mass loss steps at 263 and $280{ }^{\circ} \mathrm{C}$ are attributed to the hydroxyl group (Palmer and Frost, 2010). The higher mass loss at $280{ }^{\circ} \mathrm{C}$ is believed to be due to the loss of both $\mathrm{OH}^{-}$ and $\mathrm{CO}_{3}{ }^{2+}$. The broad mass loss at $485{ }^{\circ} \mathrm{C}$ is ascribed to the loss of carbonate as carbon dioxide $\left(\mathrm{CO}_{2}\right)$ (Frost et al., 2009). The higher temperature mass loss at $828{ }^{\circ} \mathrm{C}$ is attributed to the $\mathrm{Mg}$.

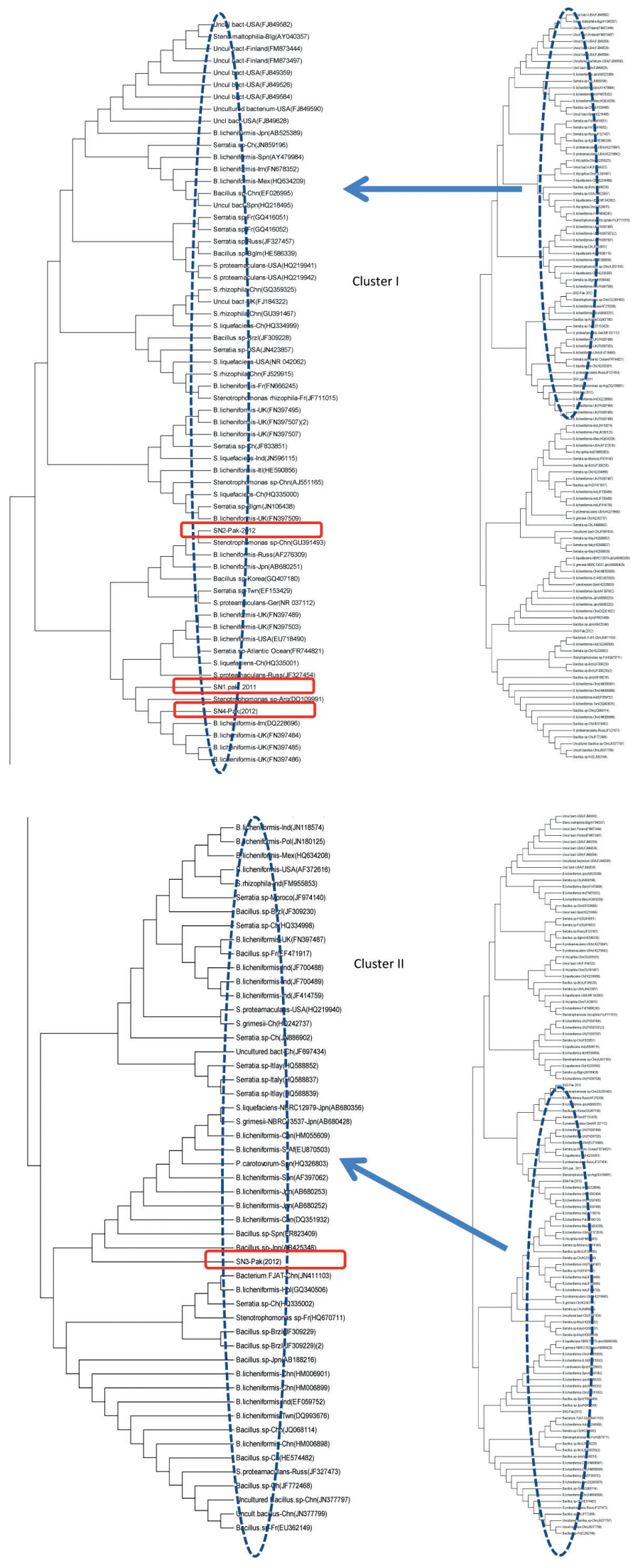

Figure 8. Phylogenetic tree showing all four isolates with related sequences in $\mathrm{NCBI}$.

Journal of Cave and Karst Studies, August 2016 • 103 


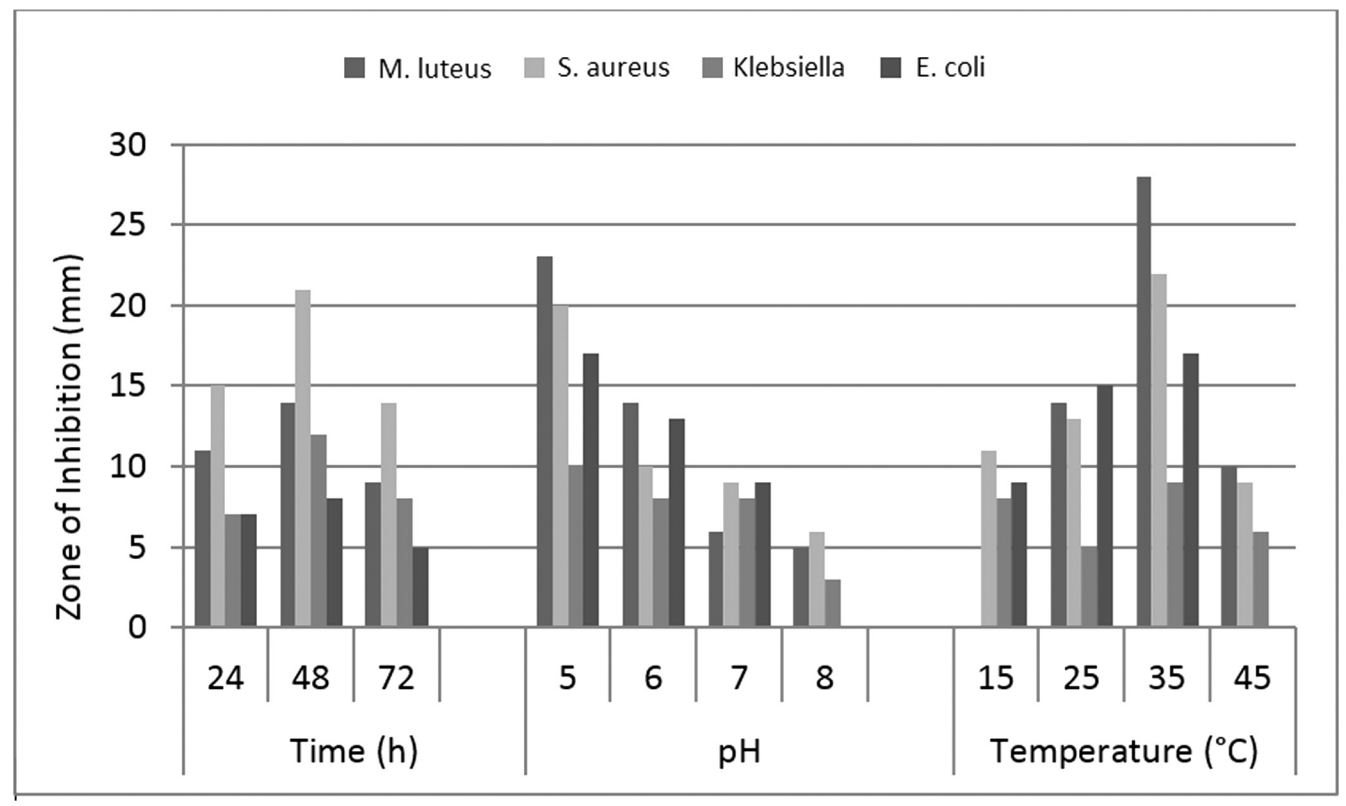

Figure 9. Effect of time of incubation, $\mathrm{pH}$, and temperature on the growth and antimicrobial activity produced by growth of Bacillus licheniformis KC2-MRL against Micrococcus luteus, Staphylococcus aureus, Klebsiella sp., and E. coli.

Clay particles were observed to have poorly crystallized clasts with angular, irregular outlines, and swirly texture with face-to-face arrangement of clay grains, as also reported by Manju et al. (2001) in the Madayi kaolin deposit, North Kerala, India. Generally, intensely weathered clay flakes show ragged edges, exhibit a rounded outline or bayshaped edges, and poor lateral dimension, with a particularly small platy thickness. Analysis shows that $\mathrm{Si}, \mathrm{Al}$, and $\mathrm{Fe}$ were enriched within the samples, which probably reflects minerals such as quartz, feldspar, clay minerals, and iron oxide (Jeong et al., 2003).

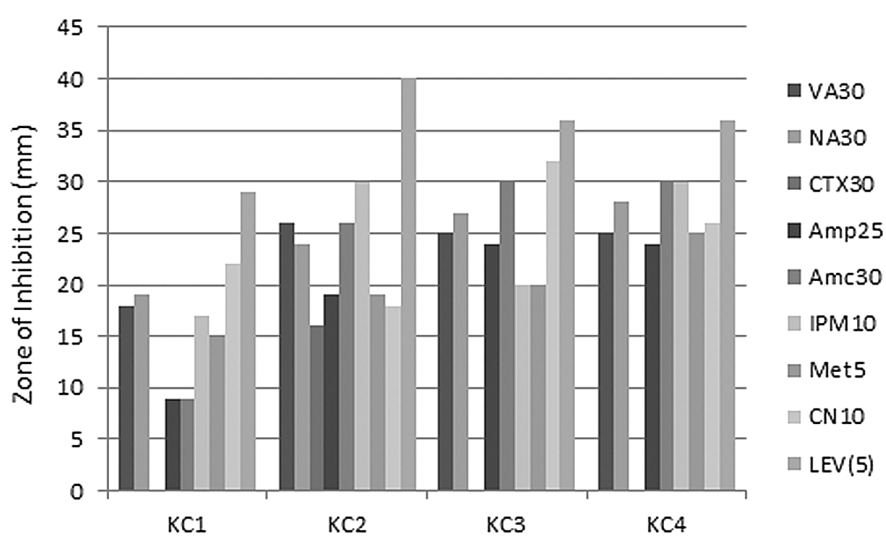

Figure 10. The results of disk-diffusion assay of the susceptability of our four antibiotic producing strains (Serratia sp. KC1-MRL, Bacillus licheniformis KC2-MRL, Bacillus sp. KC3-MRL and Stenotrophomonas sp. KC4-MRL) to selected antibiotics. Names of antibiotics can be found in the Results section of the text.
Fourier-transform infrared spectroscopy analysis showed peaks at $885 \mathrm{~cm}^{-1}, 746 \mathrm{~cm}^{-1}$, and $715 \mathrm{~cm}^{-1}$ because of presence of dolomite (White, 1964; Van Der Marel and Beutelspacher, 1976). A wide band around $1020 \mathrm{~cm}^{-1}$ is assigned to quartz, $\mathrm{SiO}_{2}$ (Russell, 1987; Ravisankar et al., 2012), and the peak at $1646 \mathrm{~cm}^{-1}$ is attributed to the bending vibration modes of water (Manoharan et al., 2007). Peaks in the region of $2800-3000 \mathrm{~cm}^{-1}$ are ascribed to the $\mathrm{C}-\mathrm{C}$ stretching that is present in the form of organic matter in the mineral contribution (Maritan et al., 2005) or may be due to $\mathrm{P}-\mathrm{OH}$ bond stretching around $2845 \mathrm{~cm}^{-1}$ and 2935 $\mathrm{cm}^{-1}$. The sharp peak at $2513 \mathrm{~cm}^{-1}$ is due to the presence of silicate minerals like quartz, nimite, musciovite, and vermiculite (Vedder, 1964). The appearance of broad band in the region of $3000 \mathrm{~cm}^{-1}$ to $3700 \mathrm{~cm}^{-1}$ is attributed to the structural water present in the mineral vermiculite and to the moisture present in the sample (Zadrapa and Zykova, 2010). The hydroxyl and water-stretching region near 3200 $\mathrm{cm}^{-1}$ for most hydrated carbonates usually consists of one or two broad bands shifted somewhat to lower frequencies due to hydrogen bonding (Nakamoto, 2008; Schrader, 1995), but the appearance of the broad band is due to the interpretation $\mathrm{OH}^{-}$and $\mathrm{H}_{2} \mathrm{O}$ in a mineral in which some minerals were participating in hydrogen bonding and some were not involved, e.g., non-hydrogen-bonded Al-OH units (White, 1964; Van Der Marel and Beutelspacher, 1976). Atomic absorption spectroscopy was performed to determine the concentrations of the elements calcium, magnesium, chromium, cobalt, nickel, zinc, copper, and lead in the cave floor soil sample, and it was found that the soil contained very high amount of calcium compared to outside soil. 


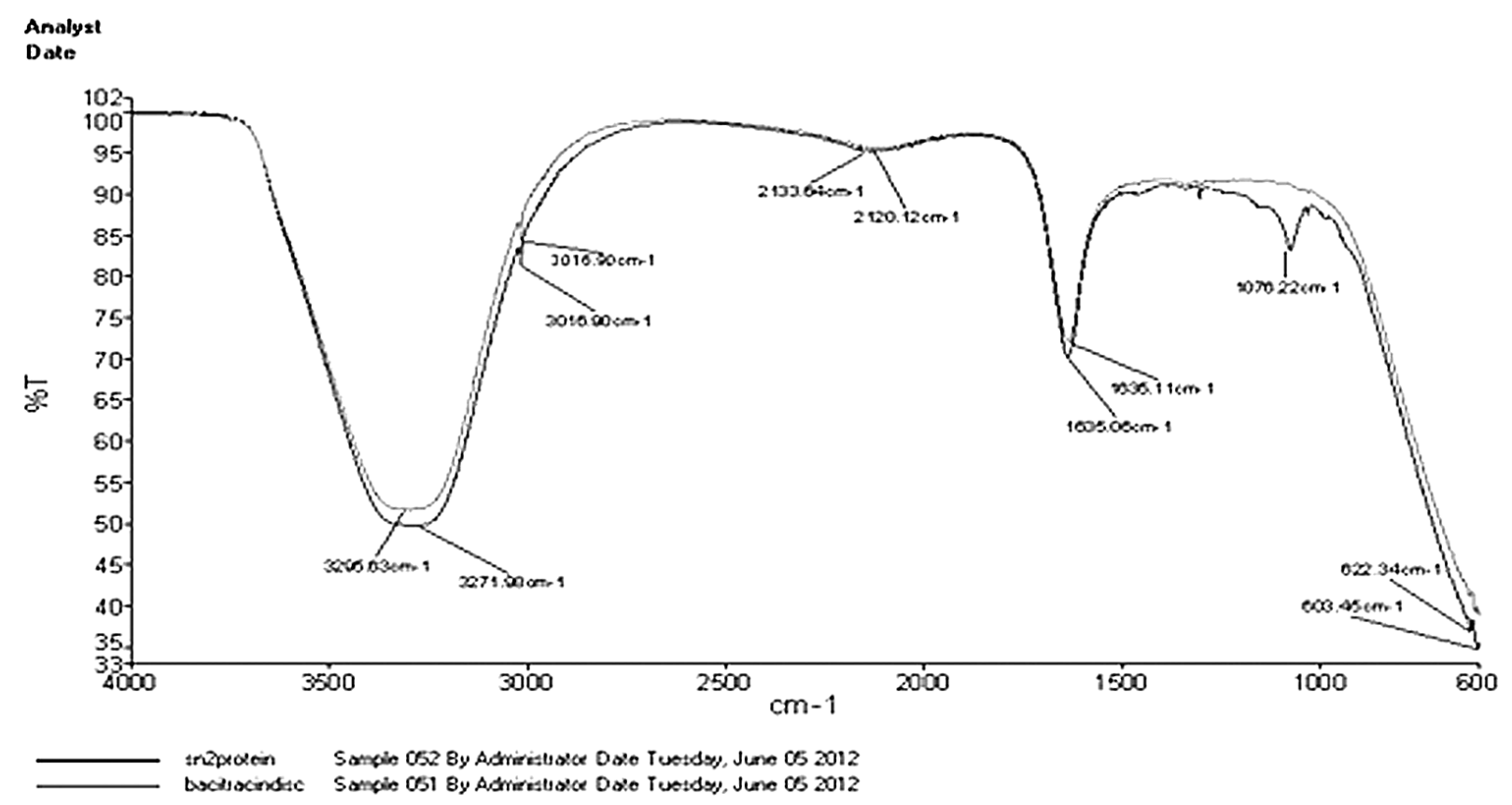

Figure 11. Comparison of Fourier-transform infrared spectra of bacitracin (lighter line) and the antibacterial compound produced by Bacillus licheniformis KC2-MRL (darker line).

\section{Microbiology}

The capacity of bacteria inhabiting karstic caves to produce valuable biologically active compounds has still not been investigated much (Tomova et al., 2013). Soil is a natural reservoir for microorganisms and their antimicrobial products (Dancer 2004). The four selected strains isolated from cave soil were screened for the production of antibiotics by using agar-well diffusion assay against Staphylococcus aureus, Klebsiella, E. coli and Micrococcus luteus. B. licheniformis KC2-MRL was selected for further analysis on the basis of the greatest zone of inhibition. In the present study, B. licheniformis KC2-MRL showed the best antimicrobial activity against $M$. luteus, followed by $S$. aureus, Klebsiella and E. coli after 48 hrs of incubation.

Studies show that caves are inhabited by different types of microorganisms having unique characteristics. A cave ecosystem has a deficiency of nutrients, which is why microorganisms present in the cave compete for the nutrients and fight for survival. Due to this struggle among microbes, they have the potential to produce antibiotics against other microbes. There are nine different groups of bacteria that have been reported to be present in caves, Proteobacteria, Acidobacteria, Planctomycetes, Chloroflexi, Bacteroidetes, Gemmatimonadetes, Nitrospirae, Actinobacteria and Firmicutes (Zhou et al., 2007; Porttillo et al., 2008). Proteobacteria are the dominant bacteria in caves (Zhou et al., 2007). The 16S rRNA gene sequences of our antibiotic producing cave bacteria have been submitted to NCBI GenBank. The isolates $\mathrm{KC1}-\mathrm{MRL}, \mathrm{KC2}-\mathrm{MRL}, \mathrm{KC} 3-\mathrm{MRL}$ and KC4-MRL were identified as Serratia sp. KC1-MRL
(Accession No. KC128829.1), Bacillus licheniformis KC2MRL (Accession No. KC128830.1), Bacillus sp. KC3-MRL (Accession No. KC128831.1), and Stenotrophomonas sp. KC4-MRL (Accession No. KC128832.1). In Magura Cave, Bulgaria, Tomonova et al. (2013) reported that Grampositive bacteria were represented by the genera Bacillus, Arthrobacter, and Micrococcus.

Soil bacterial genera such as Bacillus, Streptomyces, and Pseudomonas synthesize a high proportion of agriculturally and medically important antibiotics (Hosoya et al., 1998; Sharga et al., 2004). Peptide antibiotics are the major group of antibiotics (Pinchuk et al., 2002). Antibiotic-producing microorganisms can be found in different habitats, but the majority are common inhabitants of soil. Caves contain abundant Actinobacteria, which are valuable sources of novel antibiotics that can replace currently ineffective antibiotics (Montano and Henderson, 2012). Molecular analysis of a sample from Kashmir cave showed the presence of different bacterial strains.

Isolated strains were screened for the production of antimicrobial compounds by using agar-well diffusion assay. Ducluzeau et al. (1978) isolated Bacillus licheniformis that was active against Clostridium perfringens or Lactobacillus sp. Muhammad et al. (2009) also observed that Bacillus metabolites showed activity against $M$. luteus and $S$. aureus. Bacitracin is a major polypeptide antibiotic produced by Bacillus licheniformis and Bacillus subtilis, based on using M. luteus as a test organism (Vieira et al., 2011). B. licheniformis isolated from marine sediments showed best antimicrobial activity against pathogenic test strains $S$. aureus, E. coli and P. aeruginosa (Hosny et al., 2011). Antibiotic 
production depends upon the composition of the medium, which is required for cell biomass and for its maintenance (Stanbury et al., 1995, chap. 4). Maximum activity was found when Bacillus licheniformis was grown in nutrient broth. Similarly, Vieira et al. (2011) used nutrient broth for the growth of $B$. licheniformis when incubated at $46{ }^{\circ} \mathrm{C}$ in a shaking incubator at $150 \mathrm{rpm}$. Al-Janabi (2006), Yilmaz et al. (2006), and Al-Ajlani and Hasnain. (2010) also reported maximum production of antimicrobial compound by Bacillus sp. in nutrient broth medium at varying temperatures.

External factors can also affect the growth of microorganisms and the production of antibiotics (Marwick et al., 1999). It has been reported that environmental factors such as temperature, $\mathrm{pH}$, and incubation duration influence antibiotic production (Iwai et al., 1973). In our study, the optimum temperature for antimicrobial compound production was observed to be 30 to $35{ }^{\circ} \mathrm{C}$. Béahdy (1974) and Haddar et al. (2007) observed production of bacitracin and other antibiotics by B. licheniformis (Zarei, 2012) at $37^{\circ} \mathrm{C}$, and it was also seen at $30^{\circ} \mathrm{C}$ by Hosny et al. (2011).

We found that our selected organism showed optimum activity at pH 5-6. Flickinger and Perlman (1979) reported pH 6.5 for the optimum production of antibiotics by $B$. licheniformis. Haddar et al. (2007) found maximum bacitracin production rate $(192$ units $/ \mathrm{mL})$ at $\mathrm{pH}$ 7.5. A similar study was conducted by Gulahmadov et al. (2006) that found antimicrobial activity was best at the wide $\mathrm{pH}$ range of $6-8$ by Bacillus sp. Newly emergent infectious diseases, re-emerging diseases, and multidrug-resistant bacteria mean that there is a persistent need to produce novel antimicrobial compounds (Uzair et al., 2009).

We performed an antibiotic susceptibility test in which B. licheniformis $\mathrm{KC2}-\mathrm{MRL}$ was found resistant to cefotaxime, but was more susceptible to levofloxacin, which produces a $40 \mathrm{~mm}$ zone of inhibition. B. thuringiensis RSKK 380 was reported to be unaffected by cephazolin, cefoxitin, and cefamandole (Yilmaz et al., 2006).

Our results show that the antibacterial activity was stable up to $45^{\circ} \mathrm{C}$. A similar study by He et al. (2006) reported B. licheniformis to be stable at $25{ }^{\circ} \mathrm{C}$ for $6 \mathrm{hrs}$ and inactivated above $40{ }^{\circ} \mathrm{C}$. However, in some cases the antimicrobial compounds retained their activity even after autoclaving the sample at $121{ }^{\circ} \mathrm{C}$ (Fontoura et al., 2009; Tabbene et al., 2009; Uzair et al., 2009; Ebrahimipour et al., 2010). At the same time, sensitivity to different $\mathrm{pH}$ values was also evaluated in the present study, and the antimicrobial compound was found to be stable at $\mathrm{pH}$ 5-7. A similar study, in which antimicrobial activity was found to be stable at $\mathrm{pH} 7$, was reported by $\mathrm{He}$ et al. (2006). The stability of antibacterial activity at $\mathrm{pH} 7$ and after heat-treatment might be useful in several industrial applications (Tabbene et al., 2009). Our study showed best activity against $M$. luteus, S. aureus, and $E$. coli after 48 hours of incubation. A similar study by Aslim et al. (2002) showed the maximum zone of inhibition after 24 to 48 hrs.
Bacillus licheniformis KC2-MRL was further tested for antibiotic sensitivity by using the antibiotics vancomycin, nalidixic acid, cefotoxime, ampicillin, amoxicillin, imipenem, methicillin, Cefoten, and levofloxacin. It was found that the selected strain was more susceptible to levofloxacin, which produced a 40-mm zone of inhibition (Fig. 10).

Sirtori et al. (2006) reported clear absorption peaks at $3,500,2,925,1,639$, and $1,546 \mathrm{~cm}^{-1}$ corresponding to the $\mathrm{O}-\mathrm{H}, \mathrm{C}-\mathrm{H}, \mathrm{C}-\mathrm{N}$ and angular deformation of the $\mathrm{N}-\mathrm{H}$ bond. Kong and $\mathrm{Yu}$ (2007) also detected bands at peaks of $3100,1600-1690,1480-1575$ and $1229-1301 \mathrm{~cm}^{-1}$ that are assigned to $\mathrm{N}-\mathrm{H}, \mathrm{C}=\mathrm{O}, \mathrm{C}-\mathrm{N}$ and $\mathrm{N}-\mathrm{H}$. Kumar et al. (2010) reported absorption bands at 1670,1539, 1418, and $1488 \mathrm{~cm}^{-1}$ attributing to $\mathrm{N}-\mathrm{H}, \mathrm{C}=\mathrm{O}, \mathrm{O}-\mathrm{H}$ and $\mathrm{CO}$.

\section{Conclusion}

Our study explored the ability of cave microorganisms to produce antibiotics and characterized of the producing strain. Due to the internal acidic environment and high calcium concentration in the cave, Bacillus licheniformis $\mathrm{KC2}$ MRL grew better under acidic conditions at temperatures higher than that in the cave. Caves of Pakistan had never been explored for the presence of bacteria with regards to diversity or having ability to produce novel antimicrobial metabolites. These metabolites, as well as those produced in other caves, can be further investigated to find bioactive compounds with unique characteristics.

\section{REFERENCES}

Adetutu, E.M., and Ball, A.S., 2014, Microbial diversity and activity in caves: Microbiology Australia, v. 35, p.192-194. doi:10.1071/MA14062.

Adetutu, E.M., Thorpe, K., Shahsavari, E., Bourne, S., Cao, Xiangsheng, Fard, R.M.N., Kirby, G., and Ball, A.S., 2012, Bacterial community survey of sediments at Naracoorte Caves, Australia: International Journal of Speleolology: v. 41, p. 137-147. doi:10.5038/1827-806X.41.2.2.

Aitken, M.A., 2012, Phenol: Chloroform: Isoamyl Alcohol (25:24:1). http:// www.nhm.ac.uk/resources-rx/files/phenol-chloroform_aug12-118646.pdf. [Assessed March 23, 2014]

Al-Ajlani, M.M., and Hasnain, S., 2010, Bacteria exhibiting antimicrobial activities: Screening for antibiotics and the associated genetic studies: The Open Conference Proceedings Journal: v. 1, p. 230-238. doi:10.2174/2210289201001010230.

Al-Janabi, A.A.H.S., 2006, Identification of bacitracin produced by local isolate of Bacillus licheniformis: African Journal of Biotechnology, v. 5, p. 1600-1601.

Aslim, B., Sağlam, N., and Beyatali Y., 2002, Determination of some properties of Bacillus isolated from soil: Turkish Journal of Biology, v. 26, p. $41-48$.

Atlas, R.M., and Bartha, R., 1998, Microbial Ecology: Fundamentals \& Applications, fourth edition: San Francisco, Benjamin/Cummings, $640 \mathrm{p}$.

Barton, H.A., 2006, Introduction to cave microbiology: A review for the non-specialist: Journal of Cave and Karst Studies, v. 68, p. 43-54.

Barton, H.A., and Jurado, V., 2007, What's up down there? Microbial diversity in caves: Microbe, v. 2, no. 3, p. 132-138.

Basak, K., and Majumdar, S.K., 1975, Mineral nutrition of Streptomyces kanamyceticus for kanamycin formation: Antimicrobial Agents and Chemotherapy, v. 8, no. 4, p. 391-395. doi:10.1128/AAC.8.4.391.

Béahdy, J., 1974, Recent developments of antibiotic research and classification of antibiotics according to chemical structure: Advances in Applied Microbiology, v. 18, p. 309-406. doi:10.1016/S0065-2164(08)70573-2. 
Bérdy, J., 2005, Bioactive microbial metabolites: The Journal of Antibiotics, v. 58, no. 1, p. 1-26. doi:10.1038/ja.2005.1.

Boston, P.J., Spilde, M.N., Northup, D.E., Melim, L.A., Soroka, D.S., Kleina, L.G., Lavoie, K.H., Hose, L.D., Mallory, L.M., Dahm, C. N., Crossey, L.J., and Schelble, R.T., 2001, Cave biosignature suites: Microbes, minerals and Mars: Astrobiology, v. 1, p. 25-55.

Brock, T.D., and Madigan, M.T., 1991, Biology of Microorganisms: Upper Saddle River, New Jersey, Prentice-Hall, $860 \mathrm{p}$.

ChamLey, H., 1989, Clay Sedimentology: New York, Springer-Verlag, $623 \mathrm{p}$

Cheng, Xiaodong, Kumar, S., Posfai, J., Pflugrath, J.W., and Roberts, R.J., 1993, Crystal structure of the HhaI DNA methyltransferase complexed with S-adenosyl-L-methionine: Cell, v. 74, p. 299-307. doi:10.1016/0092-8674(93)90421-L.

Cuezva, S., Sanchez-Moral, S., Saiz-Jimenez, C., and Cañaveras, J.C., 2009, Microbial communities and associated mineral fabrics in Altamira Cave, Spain: International Journal of Speleology, v. 38, no. 1 , p. 83-92.

Dancer, S.J., 2004, How antibiotics can make us sick: The less obvious adverse effects of antimicrobial chemotherapy: The Lancet Infectious Diseases, v. 4, p. 611-619. doi:10.1016/S1473-3099(04)01145-4.

Davies, W.E., and Morgan, I.M., 2000, Geology of Caves: U.S. Geological Survey, http://www.nature.nps.gov/geology/usgsnps/cave/cave.html. Last updated on May 9, 2000 [Accessed May 1, 2013]

Demain, A.L., Aharonowitz, Y., and Martin, J.F., 1983, Metabolite control of secondary biosynthetic pathways, in Vining, L.C., ed., Biochemistry and Genetic Regulation of Commercially Important Antibiotics: London, Addison-Wesley, Biotechnology Series 2, p. 49-67.

Doak, B.W., Gallagher, P.J., Evans, L., and Muller, F.B., 1965, Lowtemperature calcination of " $\mathrm{C}$ "-grade phosphate from Christmas island -I. Growth and yield characteristics: New Zealand Journal of Agriculture Research, v. 8. p. 15-29. doi:10.1080/00288233.1965.10420020.

Doull, J.L., and Vining, L.C., 1990, Physiology of antibiotic production in actinomycetes and some underlying control mechanisms: Biotechnology Advances, v. 8, no. 1, p. 141-158. doi:10.1016/0734-9750(90)90010-9.

Ducluzeau, J.R., Dubos, F., Raibaud, P., and Abrams, G.D., 1978, Production of an antibiotic substance by Bacillus licheniformis with in the digestive tract of gnotobiotic mice: Antimicrobial Agents and Chemotherapy, v. 13. p. 97-103. doi:10.1128/AAC.13.1.97.

Dutrow, B.L., and Clark, C.M., n.d., X-Ray Powder Diffraction (XRD), http://serc.carleton.edu/research_education/geochemsheets/techniques/ XRD.htmL.

Ebrahimipour, G., Moradi, A., Mehrdad, M., Marzban, A., and Alaee, H., 2010, Evaluation of antimicrobial substance produced by a bacterium isolated from Parmacella iberica: Jundishapur Journal of Microbiology, v. 4 , p. $131-141$

Engel, A., Zondervan, I., Aerts, K., Beaufort, L., Benthien, A., Chou, L., Delille, B., Gattuso, J.-P., Harlay, J., Heemann, C., Hoffmann, L., Jacquet, S., Nejstgaard, J., Pizay, M.-D., Rochelle-Newall, E., Scheider, U., Terbrueggen, A., and Riebesell, U., 2005, Testing the direct effect of $\mathrm{CO}_{2}$ concentration on a bloom of the coccolithophorid Emiliania huxleyi in mesocosm experiments: Limnology and Oceanography, v. 50, no. 2, p. 493-507. doi:10.4319/1o.2005.50.2.0493.

Flickinger, M.C., and Perlman, D., 1979, Application of oxygen-enriched aeration in the production of bacitracin by Bacillus licheniformis: Antimicrobial Agents and Chemotherapy, v. 15, p. 282-293. doi:10.1128/ AAC.15.2.282

Fontoura, R., Spada, J.C., Silverira, S.T., Tsai, S.M., and Brandelli, A., 2009, Purification and characterization of an antimicrobial peptide produced by Pseudomonas sp. strain 4B: World Journal of Microbial Biotechnology, v. 25, p. 205-213. doi:10.1007/s11274-008-9882-4.

Frost, R.L., Hales, M.C., and Martens, W.N., 2009, Thermogravimetric analysis of selected group (II) carbonate minerals-Implication for the geosequestration of greenhouse gases: Journal of Thermal Analysis and Calorimetry, v. 95, p. 999-1005. doi:10.1007/s10973-008-9196-7.

Gauthier, M.J., 1976, Modification of bacterial respiration by a macromolecular polyanionic antibiotic produced by a marine Alteromonas: Antimicrobial Agents and Chemotherapy, v. 9, p. 361-366. doi:10.1128/AAC.9.3.361.

Georgieva-Borisova, J.Ch., 1974, Taxonomic characteristics of strain Actinomyces hygroscopicus B-255 and conditions for its antibiotic production [ $\mathrm{PhD}$ dissertation], University of Sofia, Bulgaria.

Gesheva, V., Ivanova, V., and Gesheva, R., 2005, Effects of nutrients on the production of AK-111-81 macrolide antibiotic by Streptomyces hygroscopicus: Microbiological Research, v. 160, no. 3, p. 243-248. doi:10.1016/j.micres.2004.06.005.

Groth, I., Vetterman, R., Schuetze, B., Schumann, P., and Saiz-Jimenez, C., 1999, Actinomycetes in karstic caves of northern Spain (Altamira and Tito Bustillo): Journal of Microbiological Methods, v. 36, p. 115-122. doi:10.1016/S0167-7012(99)00016-0.

Gulahmadov, S.G., Batdorj, B., Dalgalarrondo, M., Chobert, J.-M., Kuliev, A.A., and Haertlé, T., 2006, Characterization of bacteriocinlike inhibitory substances (BLIS) from lactic acid bacteria isolated from traditional Azerbaijani cheeses: European Food Research and Technology, v. 224, no. 2, p. 229-235. doi:10.1007/s00217-006-0338-5.

Haddar, H.O., Aziz, G.M., and Al-Gelawi, M.H., 2007, Optimization of bacitracin production by Bacillus licheniformis B5: Pakistan Journal of Biological Sciences, v. 10, p. 972-976. doi:10.3923/pjbs.2007.972.976.

Hancock, R.E., and Chapple, D.S., 1999, Peptide antibiotics: Antimicrobial Agents and Chemotherapy, v. 43, no. 6, p. 1317-1323.

Haque, S.F., Sen, S.K., and Pal, C.S., 1995, Nutrient optimization for the production of broad spectrum antibiotics by Streptomyces. Antibiotics Str. 15.4: Acta Microbiolgica et Immunologica Hungarica, v. 42, p. $155-162$.

He, Lili, Chen, Weiliang, and Liu, Yang, 2006, Production and partial characterization of bacteriocin like pepitdes by Bacillus licheniformis ZJU12: Microbiological Research, v. 161, p. 321-326. doi:10.1016/j. micres.2005.12.002.

Hill, C.A., 1999, Mineralogy of Kartchner Caverns, Arizona: Journal of Cave and Karst Studies, v. 61, p. 73-78.

Holt, J.G., Bergey, D.H., and Krieg, N.R., 2012, Bergey's Manual of Determinative Bacteriology, $9^{\text {th }}$ edition.

Hosny, M.S., Sheir, D.H., and Eldewany, A.I., 2011, Production of antimicrobial agent from marine bacteria isolated from Mediterranean: Australian Journal of Basic and Applied Sciences, v. 5, no. 5, p. 121-128.

Hosoya, Y., Okamoto, S., Muramatsu, H., and Ochi, K., 1998, Acquisition of certain streptomycin-resistant (str) mutations enhances antibiotic production in bacteria: Antimicrobial Agents and Chemotherapy, v. 42, p. 2041-2047.

Ikner, L.A., Toomey, R.S., Nolan, G., Neilson, J.W., Pryor, B.M., and Maier, R.M., 2007, Culturable microbial diversity and the impact of tourism in Kartchner Caverns, Arizona: Microbial Ecology, v. 53, no. 1, p. 30-42. doi:10.1007/s00248-006-9135-8.

Iwai, Y., Awaya, J., Kesado, T., Yamada, H., Ōmura, S., and Hata, T., 1973, Selective production of cerulenin by Cephalosporium caerulens KF-140: Journal of Fermentation Technology, v. 51, p. 575-581.

Jeong, Gi Young, Kim, Soo Jin, and Chang, Sae Jung, 2003, Black carbon pollution of speleothems by fine urban aerosols in tourist caves: American Mineralogist, v. 88, p. $1872-1878$.

Jensen, S., Reutergård, L., and Jansson, B., 1983, Analytical methods for measuring organochlorines and methyl mercury by gas chromatography, in FAO/SIDA Manual of Methods in Aquatic Environmental Research, Part 9, Analysis of Metals and Organochlorines in Fish: FAO Fisheries Technical Paper 212, p. 21-33

Jordán, A., 2014, Soils Going Red: Terra Rossa, blog of Soil System Sciences Division, European Geosciences Union, http://blogs.egu.eu/divisions/sss/ 2014/01/09/soils-going-red-terra-rossa. [Accessed January 3, 2015]

Jurado, V., Gonzalez, J.M., Laiz, L., and Saiz-Jimenez, C., 2006, Aurantimonas altamirensis $\mathrm{sp}$. nov, a member of the order Rhizobiales isolated from Altamira Cave: International Journal of Systemic Evolutionary Microbiology, v. 56, p. 2583-2585. doi:10.1099/ijs.0.64397-0.

Koneman, E.W., 2006, Color Atlas and Textbook of Diagnostic Microbiology, sixth edition, Philadelphia, Lippincott Williams \& Wilkins, 1736 p.

Kong, Jilie, and Yu, Shaoning, 2007, Fourier transform infrared spectroscopic analysis of protein secondary structures: Acta Biochimica Biophysica Sinica, v. 39, p. 549-559. doi:10.1111/j.17457270.2007.00320.x.

Kumar, S., Malhotra, R., and Kumar, D., 2010, Antihyperglycemic, antihyperlipidemic and antioxidant activities of Euphorbia hirta stem extract: International Research Journal of Pharmacy, v. 1, p. 150-156.

Laiz, L., Groth, I., Gonzalez, I., and Sáiz-Jiménez, C., 1999, Microbiological study of the dripping waters in Altamira cave (Santillana del Mar, Spain): Journal of Microbiological Methods, v. 36, no. 1, p. 129-138. doi:10.1016/S0167-7012(99)00018-4.

Lavoie, K.H., and Northup, D.E., 2005, Bacteria as indicators of human impact in caves, in Rea, G.T. ed., Proceedings of the 2005 National Cave and Karst Management Symposium: NCKMS Steering Committee, p. $40-47$. 
Liu, Chao-Min, McDaniel, L., and Schaffner, C.P., 1975, Factors affecting the production of candicidin: Antimicrobial Agents and Chemotherapy, v. 7, no. 2, p. 196-202. doi:10.1128/AAC.7.2.196.

Luong, P., Kinch, L.N., Brautigam, C.A., Grishin, N.V., Tomchick, D.R., and Orth, K., 2010, Kinetic and structural insights into the mechanism of AMPylation by VopS Fic domain: Journal of Biological Chemistry, v. 285 , no. 26 , p. 20155-20163. doi:10.1074/jbc.M110.114884.

Manju, C.S., Nair, V.N., and Lalithambika, M., 2001, Mineralogy, geochemistry and utilization study of the Madayi kaolin deposit, North Kerala, India: Clays and Clay Minerals, v. 49, p. 355-369.

Manoharan, C., Venkatachalapathy, R., Dhanapandian, S. and Deenadayalan, K., 2007, FTIR and Mössbauer spectroscopy applied to the study of archaeological artefacts from Maligaimedu, Tamil Nadu, India: Indian Journal of Pure and Applied Physics, v. 45, p. 860-865.

Maritan, L., Mazzoli, C., Nodari, L., and Russo, U., 2005, Second Iron Age grey pottery from Este (northeastern Italy): Study of provenance and technology: Applied Clay Science, v. 29, p. 31-44. doi:10.1016/j. clay.2004.09.003.

Marwick, J.D., Wright, P.C., and Burgess, J.G., 1999, Bioprocess intensification for production of novel marine bacterial antibiotics through bioreactor operation and design: Marine Biotechnology, v. 1, p. 495-507. doi:10.1007/PL00011806.

Millot, G., 1970, Geology of Clays: Weathering, Sedimentology, Geochemistry: Berlin, Springer Verlag, 430 p. doi:10.1007/978-3-662-41609-9.

Montano, E.T., and Henderson, L.O., 2012, Studies of antibiotic production by cave bacteria, in Cheeptham, N., ed., Cave Microbiomes: A Novel Resource for Drug Discovery: New York, Springer-Verlog, Springer Briefs in Microbiology 1, p. 109-130. doi:10.1007/978-14614-5206-5.

Muhammad, S.A., Ahmad, S., and Hameed, A., 2009, Antibiotic production by thermophilic Bacillus specie SAT-4: Pakistan Journal of Pharmaceutical Sciences, v. 22. p. 339-345.

Nakamoto, K., 2008, Infrared and Raman Spectra of Inorganic and Coordination Compounds, Part A: Theory and Applications in Inorganic Chemistry, sixth edition: New York, John Wiley and Sons, $419 \mathrm{p}$. doi: $10.1002 / 9780470405840$.

Nelson, A.P., 1996, What would real little green men tell us about evolution-and God? (Review of Davies, P., Are we alone? Philosophical Implications of the Discovery of Extraterrestrial Life: New York, Basic Books, 160 p.): Origens \& Design, v. 17, no. 1.

Nissen-Meyer, J., and Nes, I.F., 1997, Ribosomally synthesized antimicrobial peptides: Their function, structure, biogenesis, and mechanism of action: Archives of Microbiology, v. 167, no. 2-3, p. 67-77. doi:10.1007/s002030050418.

Northup, D.E., and Lavoie K.H., 2004, Microorganisms in caves, in Gunn, J., ed., Encyclopedia of Caves and Karst Science: London, Taylor and Francis, p. 506-509.

Onaga, L., 2001, Cashing in on nature's pharmacy: EMBO Reports, v. 2, p. 263-265. doi:10.1093/embo-reports/kve077.

Palmer, S.J., and Frost, R.L., 2010, Thermal decomposition of Bayer precipitates formed at varying temperatures: Journal of Thermal Analysis and Calorimetry, v. 100, p. 27-32. doi:10.1007/s10973-009-0136-y.

Park Chang-Woong, Lee Hye-Sook, and Kim Yong-Sik, 1998, Mechanism of $\mathrm{MPP}^{+}$-induced cytotoxicity in human neuroblastoma SH-SY5Y: Journal of Toxicological Sciences, v. 23, suppl., p. 184-188. doi:10.2131/jts.23.SupplementII_184.

Pereda, A., Summers, R.G., Stassi, D.L., Ruan, X., and Katz, L., 1998, The loading domain of the erythromycin polyketide synthase is not essential for erythromycin biosynthesis in Saccharopolyspora erythraea: Microbiology, v. 144, no. 2, p. 543-553. doi:10.1099/00221287144-2-543

Pinchuk, I.V., Bressollier, P., Sorokulova, I.B., Verneuil, B., and Urdaci, M.C., 2002, Amicoumacin antibiotic production and genetic diversity of Bacillus subtilis strains isolated from different habitats: Research in Microbiology, v. 153, p. 269-276. doi:10.1016/S0923-2508(02) 01320-7.

Portillo, M.C., Gonzalez, J.M., and Saiz-Jimenez, C., 2008, Metabolically active microbial communities of yellow and grey colonizations on the walls of Altamira Cave, Spain: Journal of Applied Microbiology, v. 104, p. 681-691. doi:10.1111/j.1365-2672.2007.03594.x

Ravisankar, R., Eswaran, P., Rajalakshmi, A., Chandrasekaran, A., Thillaivelavan, K.K., and Dhinakaran, B., 2012, Beach rock from the south east Coast of Tamilnadu, India. A spectroscopic study: Advances in Applied Science Research, v. 3, p. 95-102.
Rigali, S., Titgemeyer, F., Barends, S., Mulder, S., Thomae, A.W., Hopwood, D.A., and van Wezel, G.P., 2008, Feast or famine: The global regulator DasR links nutrient stress to antibiotic production by Streptomyces: EMBO Reports, v. 9, no. 7, p. 670-675. doi:10.1038/embor. 2008.83.

Riley, M.A., and Wertz, J.E., 2002, Bacteriocins: Evolution, ecology, and application: Annual Review of Microbiology, v. 56, p. 117-137. doi:10.1146/annurev.micro.56.012302.161024.

Russell, J.D., 1987, Infrared methods, in Wilson, M.J., ed., A Handbook of Determinative Methods in Clay Mineralogy: Glasgow, Blackie, p. 133-173.

Sanchez, S., and Demain, A.L., 2002, Metabolic regulation of fermentation processes: Enzyme and Microbial Technology, v. 31, no. 7, p. 895-906. doi:10.1016/S0141-0229(02)00172-2.

Schrader, B., ed., 1995, Infrared and Raman Spectroscopy: Methods and Applications: Weinheim, Wiley-VCH. doi:10.1002/9783527615438.

Schwabe, S.J., Carew, J.L., and Mylroie, J.E., 1993, The petrology of Bahamian Pleistocene eolianites and flank margin caves: Implications for late Quaternary island development, in White, B., ed., Proceedings of the Sixth Symposium on the Geology of the Bahamas: San Salvador, Bahamian Field Station, p. 149-164.

Sharga, B.M., Nikolaychuk, V.I., and Maga, M.I., 2004, Comparative IR spectrometry of antimicrobial substances derived antibiotic from Bacillus: Journal of the Uzhhorod National University, Series Biology, v. 15 , p. $75-77$.

Simmons, J.A., Currie, W.S., Eshleman, K.N., Kuers, K., Monteleone, S., Negley, T.L., Pohlad, B.R., and Thomas, C.L., 2008, Forest to reclaimed mine land use change leads to altered ecosystem structure and function: Ecological Applications, v. 18, no. 1, p. 104-118. doi:10.1890/07-1117.1.

Singh, Atul Pratap, and Mishra, S., 2013, Studies on antibiotic production by soil microflora and their biochemical characterization from different industrial waste polluted soil samples in (Uttar Pradesh and Uttarakhand) India: IOSR Journal of Pharmacy and Biological Science, v. 7, no. 4. p. 32-43. doi: 10.9790/3008-0743243.

Sirtori, L.R., Cladera-Olivera, F., Lorenzini, D.M., Tsai, S., and Brandelli, A., 2006, Purification and partial characterization of an antimicrobial peptide produced by Bacillus sp. strain P45, a bacterium from the Amazon basin fish Piaractus mesopotamicus: Journal of General and Applied Microbiology, v. 52, p. 357-363. doi:0.2323/ jgam. 52.357

Solivery, S., Mendosa, A., and Arias, M.-E., 1988, Effect of different nutrients on the production of polyene antibiotics PA-5 and PA-7 by Streptoverticillium sp. 43/16 in chemically defined medium: Applied Microbiology and Biotechnology, v. 28, p. 254-257. doi:10.1007/ BF00250450.

Stanbury, P.F., Whitaker, A., and Hall, S.J., 1995, Principles of Fermentation Technology, second edition: Oxford, Butterworth-Heinemann, $376 \mathrm{p}$.

Stranks, D.R., Heffernan, M.L., Lee Dow, K.C., McTigue, P.T., and Withers, G.R.A., 1970, Chemistry: A Structural View, second edition: Carlton, Victoria, Melbourne University Press, $516 \mathrm{p}$.

Tabbene, O., Karkouch, I., Elkahoui, S., Cosette, P., Mangoni, M.-L., Jouenne, T., and Limam, F., 2009, A new antibacterial and antioxidant S07-2 compound produced by Bacillus subtilis B38: FEMS Microbiology Letters, v. 303, p. 176-182. doi:10.1111/j.1574-6968.2009.01875.x.

Tanaka, Y., Hosaka, T., and Ochi, K., 2010, Rare earth elements activate the secondary metabolite-biosynthetic gene clusters in Streptomyces coelicolor A3(2): The Journal of Antibiotics, v. 63, p. 477-481. doi:10.1038/ja.2010.53.

Tardy, Y., and Nahon, D., 1985, Geochemistry of laterites, stability of Al-goethite, Al-hematite, and $\mathrm{Fe}$ (super 3+)-kaolinite in bauxites and ferricretes: An approach to the mechanism of concretion formation: American Journal of Science, v. 285, p. 865-903. doi:10.2475/ajs.285.10.865.

Taylor, J.C., 1991, Computer programs for standardless quantitative analysis of minerals using the full powder diffraction profile: Powder Diffraction, v. 6, p. 2-9. doi:10.1017/S0885715600016778.

Taylor, J.C., and Clapp, R.A., 1992, New features and advanced applications of SIROQUANT: A personal computer XRD full profile quantitative analysis software package: Advances in X-Ray Analysis, v. 35, p. $49-55$.

Thompson, J.D., Higgins, D.G., and Gibson, T.J., 1994, CLUSTAL W: Improving the sensitivity of progressive multiple sequence alignment through sequence weighting, position-specific gap penalties and weight 
matrix choice: Nucleic Acids Research, v. 22, p. 4673-4680. doi:10.1093/nar/22.22.4673.

Tomova, I., Lazarkevich, I., Tomova, A., Kambourova, M., and VasilevaTonkova, E., 2013, Diversity and biosynthetic potential of culturable aerobic heterotrophic bacteria isolated from Magura Cave, Bulgaria: International Journal of Speleology, v. 42, no. 1, p. 65-76.

Uzair, M., Ahmed, M., and Nazim, K., 2009, Effect of industrial waste on seed bank and growth of wild plants in Dhabeji area, Karachi, Pakistan: Pakistan Journal of Botony, v. 41, p. 1659-1665.

Van Der Marel, H.W., and Beutelspacher, H., 1976, Atlas of Infrared Spectroscopy of Clay Minerals and Their Admixtures: Amsterdam, Elsevier Publishing Company, 396 p.

Vedder, W., 1964, Correlations between infrared spectrum and chemical composition of mica: American Mineralogist, v. 49, p. 736-768.

Vicente, M.A., Elsass, F., Molina, E., and Robert, M., 1997, Palaeoweathering in slates from the Iberian Hercynian Massif (Spain); investigation by TEM of clay mineral signatures: Clay Minerals, v. 32, p. $435-451$.

Vieira, A.M., Alencar, A.A., and Alves Da Silva, C.A., 2011, Bacitracin produced by Bacillus licheniformis (UCP 1014) using economic medium formulated with milk serum [abstract]: Holos Environment, v. 11, suppl. 1 (Resumos apresentados no V Simpósio de Microbiologia Aplicada, Rio Claro), p. 20

Vogel, P.N., Mylroie, J.E., and Carew, J.L., 1990, Limestone petrology and cave morphology on San Salvador Island, Bahamas: Cave Science, v. 17, p. 19-30.

Voitovich, V.B., Lavrenko, V.A., Voitovich, R.F., and Golovko, E.I., 1994, The effect of purity on high-temperature oxidation of zirconium: Oxidation of Metals, v. 42, p. 223-237. doi:10.1007/BF01052024.

Weaver, C.E., 1989, Clays, Muds, and Shales: Amsterdam, Elsevier, Scientific Publications, Development in Sedimentology 44, 819 p.
White, R.G., 1964, Handbook of Industrial Infrared Analysis: New York, Plenum Press, $440 \mathrm{p}$.

Yeaman, M.R., and Yount, N.Y., 2003, Mechanisms of antimicrobial peptide action and resistance: Pharmacological Reviews, v. 55, no. 1, p. 27-55. doi:10.1124/pr.55.1.2.

Yilmaz, M., Soran, H., and Beyatli, Y., 2006, Antimicrobial activities of some Bacillus spp. strains isolated from the soil: Microbiological Research, v. 161, p. 127-131. doi:10.1016/j.micres.2005.07.001.

Yousaf, M., 1997, Studies on the cultural conditions for the production of antibiotic bacitracin by B. licheniformis [Ph.D. dissertation], Islamia University, Bahawalpur.

Zadrapa, P., Zykova, J., Tripska, E., Malac, J., and Kovarova, L., 2010, Preparation of (ethylene-methacrylic acid) copolymer/vermiculite composites, in Frazao, O., ed., Advances in Sendsors, Signals and Materials: WSEAS Press, p. 75-78.

Zarei, I., 2012, Biosynthesis of bacitracin in stirred fermenter by Bacillus licheniformis using defatted oil seed cakes as substrate: Modern Applied Science, v. 6, no. 2, p. 30-36. doi:10.5539/mas.v6n2p30.

Zhang, Qin, Zhu, Bao-Quan, and Hu, Hai-Feng, 2008, Activated antibiotic production by inducing resistance to apreomycin, Streptomyces lividans and Streptomyces coelicolor: Chinese Journal of Natural Medicines, v. 6, no. 1, p. 57-62. doi:10.1016/S1875-5364(09)60006-6.

Zhao, Qiguo, and Yang, Hao, 1995, A preliminary study on red earth and changes of Quaternary environment in south China: Quaternary Sciences, v. 15 , p. 107-116.

Zhou, Xin, Kjer, K.M., and Morse, J.C., 2007, Associating larvae and adults of Chinese Hydropsychidae caddisflies (Insecta: Trichoptera) using DNA sequences: Journal of the North American Benthological Society, v. 26, p. 719-742. doi:10.1899/06-089.1.

Ziad, W., 2006, A queen consort of the early Kidarite principality of Kashmir Smast:Oriental Numismatic Society Journal, no. 187. 